\title{
Terrestrial paleoenvironment characterization across the Permian-Triassic boundary in South China
}

\author{
Antoine Bercovici ${ }^{\mathrm{a}, *}$, Ying Cui ${ }^{\mathrm{b}}$, Marie-Béatrice Forel ${ }^{\mathrm{c}}$, Jianxin $\mathrm{Yu}^{\mathrm{c}}$, Vivi Vajda ${ }^{\mathrm{a}}$ \\ a Department of Geology, Lund University, Sölvegatan 12, SE-223 62 Lund, Sweden \\ ${ }^{\mathrm{b}}$ Department of Geosciences, 512 Deike Building, The Pennsylvania State University, University Park, PA 16802, USA \\ 'State Key Laboratory of Biogeology and Environmental Geology of Ministry of Education, China University of Geosciences, Wuhan 430074, People's Republic of China
}

\section{A R T I C L E I N F O}

\section{Article history:}

Received 28 April 2014

Received in revised form 1 July 2014

Accepted 2 November 2014

Available online 24 November 2014

\section{Keywords:}

Permian-Triassic boundary

Palynology

Biostratigraphy

Mass-extinction

Fungal spike

\begin{abstract}
A B S T R A C T
Well-preserved marine fossils in carbonate rocks permit detailed studies of the end-Permian extinction event in the marine realm. However, the rarity of fossils in terrestrial depositional environments makes it more challenging to attain a satisfactory degree of resolution to describe the biotic turnover on land. Here we present new sedimentological, paleontological and geochemical (X-ray fluorescence) analysis from the study of four terrestrial sections (Chahe, Zhejue, Mide and Jiucaichong) in Western Guizhou and Eastern Yunnan (Yangtze Platform, South China) to evaluate paleoenvironmental changes through the Permian-Triassic transition.

Our results show major differences in the depositional environments between the Permian Xuanwei and the Triassic Kayitou formations with a change from fluvial-lacustrine to coastal marine settings. This change is associated with a drastic modification of the preservation mode of the fossil plants, from large compressions to small comminuted debris. Plant fossils spanning the Permian-Triassic boundary show the existence of two distinct assemblages: In the Xuanwei Formation, a Late Permian (Changhsingian) assemblage with characteristic Cathaysian wetland plants (mainly Gigantopteris dictyophylloides, Gigantonoclea guizhouensis, G. nicotianaefolia, G. plumosa, G. hallei, Lobatannularia heinanensis, L. cathaysiana, L. multifolia, Annularia pingloensis, A. shirakii, Paracalamites stenocostatus, Cordaites sp.) is identified. In the lowermost Kayitou Formation, an Early Triassic (Induan) Annalepis-Peltaspermum assemblage is shown, associated with very rare, relictual gigantopterids. Palynological samples are poor, and low yield samples show assemblages almost exclusively represented by spores. A $\sim 1 \mathrm{~m}$ thick zone enriched in putative fungal spores was identified near the top of the Xuanwei Formation, including diverse multicellular forms, such as Reduviasporonites sp. This interval likely corresponds to the PTB "fungal spike" conventionally associated with land denudation and ecosystem collapse. While the floral turnover is evident, further studies based on plant diversity would be required in order to assess contribution linked to the end-Permian mass extinction versus local paleoenvironmental changes associated with the transition between the Xuanwei and Kayitou formations.
\end{abstract}

(c) 2014 Elsevier Ltd. All rights reserved.

\section{Introduction}

The end-Permian ( $\sim 252.2 \mathrm{Ma})$ is associated with the largest mass extinction event in Earth's history, representing the extinction of more than $90 \%$ of marine species, $70 \%$ of terrestrial vertebrates, and drastic restructuring of ecosystems (Erwin, 2006; Vajda and Bercovici, 2014). Numerous studies have been conducted to characterize the biotic changes (Payne and Clapham, 2012; Chen and Benton, 2012; Crasquin and Forel, 2014; Chen et al., 2014a, 2014b; and references therein) and environmental disturbances

\footnotetext{
* Corresponding author.

E-mail address: antoine.bercovici@geol.lu.se (A. Bercovici).
}

(Xie et al., 2007; Sun et al., 2012; Romano et al., 2012; Retallack, 2013; Cui et al., 2013; Benton and Newell, 2014; Cui and Kump, 2014; Feng and Algeo, 2014) associated with the end-Permian extinction event (EPE, Burgess et al., 2014) within marine successions. In recent years, emphasis has been directed to exposures located along the Yangtze Platform in South China, culminating in the definition of the Global Stratotype Section and Point (GSSP) for the Permian-Triassic boundary (PTB) at the Meishan section (Zhejiang province, west of Shanghai, Yin et al., 2001). One unique aspect of the Yangtze Platform is the occurrence of multiple sections preserving the PTB, representing the complete transition from marine, through coastal, and to terrestrial depositional environments. This enables correlation between the marine and terrestrial biostratigraphic records. The second unique aspect is the presence 
of seemingly continuous sections, i.e. a Permian part free of red beds, as opposed to the vast majority of terrestrial successions of Late Permian and PTB age elsewhere in the paleotropics (Lucas et al., 2006; Bourquin et al., 2011 and references therein). This implies better preservation of organic matter and the existence of latest Permian plant fossils in strata preceding the mass extinction event. The terrestrial and transitional PTB sections of Guizhou, Sichuan and Yunnan provinces have thus received increasing attention over recent years. However, the PTB interval remains poorly resolved in the terrestrial realm due to the lack of systematic paleontological studies and paleoenvironmental interpretation. Fossil plants and palynological assemblages spanning the PTB are exceedingly rare, but well-preserved macrofloral assemblages exist in South China. Early description of the macroflora and miospores was published in the 80's (Ouyang and Li, 1980; Ouyang, 1982, 1986). Most recent work has been directed towards the definition of a continental parastratotype completing the Meishan PTB GSSP, and there is growing interest in defining an equivalent biostratigraphic zoning within terrestrial settings. In support of this objective, description of the paleobotanical and palynological assemblages has been conducted over the past decade (Wang and Yin, 2001; Zhang et al., 2006; Peng et al., 2006; Yin et al., 2007; Yu et al., 2007, 2008, 2010; Peng and Shi, 2009; Xiong and Wang, 2011, and references therein). Recently, Shen et al. (2011a) presented new high-resolution radiometric dates of several bentonite layers from the Meishan GSSP and other coastal marine and terrestrial PTB sections in South China, facilitating correlations between the PTB sections of the Yangtze Platform.

We document new data from the study of two classical sections (Chahe and Zhejue, Western Guizhou) and one coastal transitional PTB section (Mide, Eastern Yunnan). We also describe a new PTB section (Jiucaichong, Western Guizhou) within the Yangtze Platform. Paleoenvironmental characterization of the PTB transition was performed using detailed sedimentological analysis complemented by paleobotanical and palynological studies. Additionally, major element geochemistry was performed using X-ray fluorescence (XRF) analysis. Results are discussed in the context of the previously proposed placement of the PTB and demise of the terrestrial ecosystems associated with the end-Permian mass extinction event. Palynofacies analysis has been carried out for the first time on organic residues from these PTB successions. Palynofacies analysis is an especially valuable tool when studying poorly preserved palynological assemblages as it can provide important paleoenvironmental information and complement lithological and biostratigraphical data to improve correlations.

\section{Geological background}

\subsection{General stratigraphy}

Three main formations are recognized through the terrestrial PTB successions of South China: the Xuanwei, the Kayitou and the Dongchuan formations. The Xuanwei Formation rests unconformably on the Emeishan basalts and is of latest Permian age (Wuchiapingian and Changhsingian) age (He, 2007). The Xuanwei Formation consists mainly of terrigenous siliciclastic deposits with intercalations of organic-rich mudstones and coal seams. Eastwards, coeval formations are represented by marine limestones of the Wangjiazhai Formation (Sichuan) and Changhsing Formation (Meishan). The Xuanwei Formation is conformably overlain by the Kayitou Formation, which is a $10-30 \mathrm{~m}$ massive and homogeneous silty sandstone succession. The rocks of the Kayitou Formation are finely variegated and grade from tan-green to yellow to purple-red towards the top. The Kayitou Formation gradually changes to facies typical of the overlying Dongchuan Formation represented by a thick succession of purple-red terrigenous siliciclastic sandstones and mudstones. Eastwards, lateral correlative strata are represented by marine limestones of the Feixianguan Formation (Sichuan) and Yinkeng Formation (Meishan).

\subsection{The Permian-Triassic boundary in South China}

Accurate chronological correlation is crucial for establishing a precise sequence of events spanning the PTB. The primary marker of the PTB at the Meishan GSSP is the First Appearance Datum (FAD) of the conodont Hindeodus parvus, identified in the middle of limestone Bed 27 (Yin et al., 2001, 2007). The EPE is, however, spread over an interval of $\sim 50 \mathrm{~cm}$ starting prior to the PTB at the top of Bed 24, and extend up to Bed 29 (Xie et al., 2005; Yin et al., 2007; Crasquin et al., 2010; Forel and Crasquin, 2011; Song et al., 2013). This interval is marked by the disappearance of many animal and plant groups, each recorded by their Last Appearance Datum (LAD). The EPE is also characterized by widespread oceanic anoxia and rapid carbon isotopic excursions, broadly used as a geochemical correlation tool. On land, the collapse of terrestrial ecosystems and floras has been characterized by the proliferation of Reduviasporonites sp., variably interpreted as a saprophytic fungus (Sephton et al., 2008; Visscher et al., 2004, 2011) or as an opportunistic algae (Afonin et al., 2001; Foster et al., 2002), but nonetheless occurring worldwide (Eshet et al., 1995; Visscher et al., 1996; Steiner et al., 2003; Sandler et al., 2006).

Other methods for correlating the PTB have been suggested, mostly based on lithostratigraphy and clay mineral signatures (Zhang et al., 2006). The concept of the Permian-Triassic Boundary Stratigraphic Set (PTBST) was defined by Peng et al. (2005) as representing a threefold lithostratigraphic succession encompassing the PTB. At the marine Meishan section, the PTBST is represented by a claystone unit (Beds 25 and 26), followed by a limestone bed that contains the PTB as defined by the FAD of Hindeodus parvus (Bed 27), overlain by another claystone (Bed 28). This threefold lithostratigraphic succession was conventionally correlated between exposures across the entire Yangtze platform and referred to as "eventostratigraphy" (Peng et al., 2005). Westward, the PTBST was defined at coastal sections, such as Zhongzhai (where the PTBST is represented by a clay bed, a sandy limestone unit and another clay bed, respectively Beds 12,13 and 14), and terrestrial sections, such as Chahe (where the PTBST is represented by a clay bed, a silty sandstone unit and another clay bed, respectively Beds 66, 67 and 68).

\section{Study area and methods}

Exposures of the terrestrial PTB are accessible in rural areas around Xuanwei city, Yunnan province (Fig. 1). The terrestrial sections Chahe (48R 0385932, UTM 2953327) and Zhejue (48R 0394488, UTM 2943109) are located along roadcuts, whereas the newly described Jiucaichong section represents hill face exposure (48R 0398849, UTM 2944904), all in Western Guizhou. The transitional coastal Mide section (48R 0444118, UTM 2888507) in Eastern Yunnan is located along a dirt road. It is noteworthy that the Mide section corresponds to two different sections in the literature, Mide A and Mide B (Yu, 2008). Mide A is no longer accessible, but a new outcrop spanning the PTB interval was identified at a distance of several hundred meters. Therefore, "Mide" in this paper refers to the newly studied Mide B section.

\subsection{Sedimentology and facies analysis}

The four sections were logged at a scale of 1:40 using a measuring tape and Jacob staff (Figs. 2-5). Six main facies were identified 


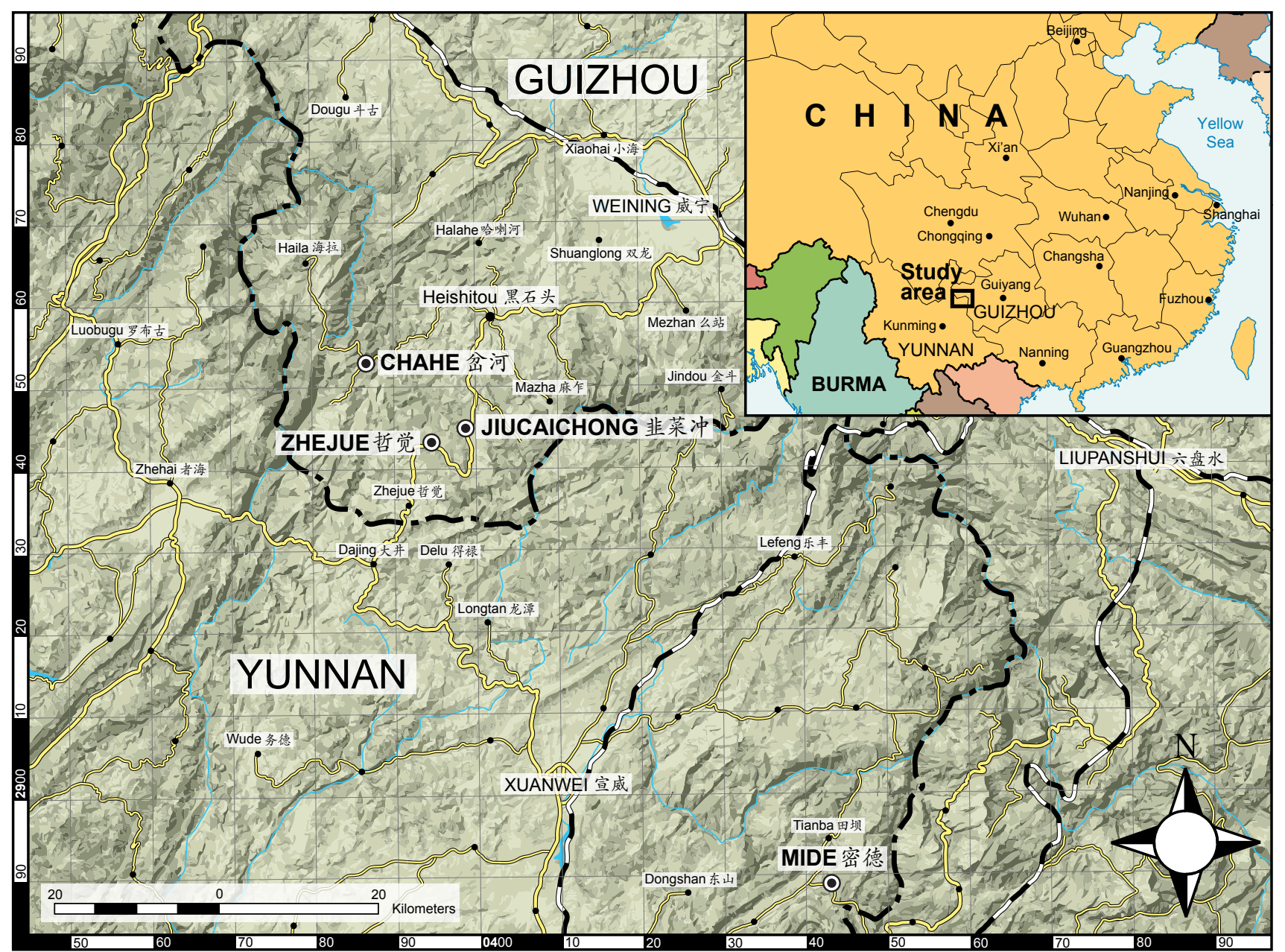

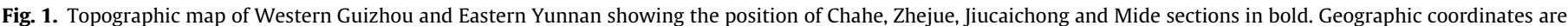
given as a $10 \mathrm{~km}$ UTM grid.

(Table 1). Previous work on the Chahe, Zhejue and Mide sections established a stratigraphic bed numbering scheme (Zhao, 2003; Yu, 2008) that we applied to the ordination of beds in our study. For the new Jiucaichong section we propose a bed numbering scheme in which each sedimentary package is defined as a fining upward genetic sequence representing a coarse rock unit (sandstone to siltstone) capped by a fine unit (siltstone to mudstone). Sedimentological characterization involved analysis of texture, sedimentary structures, paleosol development, paleocurrent orientation, erosional surfaces and paleontological content (mainly plant fossils and bivalves). At the Mide section, abundant ostracods were observed and sampled from the Kayitou Formation (Bed 25), providing additional data for paleoenvironmental interpretation.

\subsection{Paleobotany}

A traditional field census of plant fossil was performed on a total of six hundred and two specimens, most identified at the genus level. Each stratigraphic occurrence was given a census number (30 for Chahe, 10 for Jiucaichong and 10 for Zhejue, Figs. 2 5 and Table 2). Other intervals hosting unidentified plant fossil debris are also indicated on the stratigraphic logs.

\subsection{Palynology}

The sections were sampled for palynology at regular intervals focusing on the mudstone units. One hundred and sixteen samples were processed according to standard palynological procedures (Traverse, 2007) at the China University of Geosciences, Wuhan
(China). Each $10 \mathrm{~g}$ sample was crushed to $1 \mathrm{~mm}$ diameter granules and treated with dilute hydrochloric acid $(\mathrm{HCl})$ to remove calcium carbonate. Each sample was subsequently macerated in $40 \%$ hydrofluoric acid (HF) for $72 \mathrm{~h}$. Fluorosilicates were removed by immersing the residues in hot $\mathrm{HCl}$ for $10 \mathrm{~min}$. The remaining part of the processing was conducted at Lund University, Sweden, where residues were sieved through $160 \mu \mathrm{m}$ and $10 \mu \mathrm{m}$ meshes. Abundant humic acids in some of the samples were removed with $10 \% \mathrm{NaOH}$ for $16 \mathrm{~h}$ followed by multiple rinses through a $10 \mu \mathrm{m}$ mesh. The oxidation process was controlled and each sample was verified for palynological content before and after the procedure (Supplement Table 1). Residues were permanently mounted in polyester resin on a minimum of three microscope slides per sample. A representative selection of palynomorphs was photographed and post-processed using extended depth of field reconstruction (Bercovici et al., 2009a). Sample 11J012 was also sent for independent processing to Global Geolab in Canada to compare process quality and yield. Out of the 116 samples processed, 47 (40.5\%) were barren of organic matter. Out of the remainders, 47 (40.5\%) were barren of spores and pollen, leaving only 22 samples (19.0\%) with very little recovery (Supplement Table 1). Because of the poor recovery and few visible palynomorphs on each slide, relative abundance and diversity studies were not carried out.

The stratigraphic positions of samples are precisely logged (Figs. 2-5), except for the basal samples from the Zhejue section (11Z001 to 11Z007), which were collected without stratigraphic positioning in the unmeasured lower part of the section. They correspond to a series of "coal beds" or organic rich mudstones located approximately 20-30 m below Bed 27 (Fig. 3). 


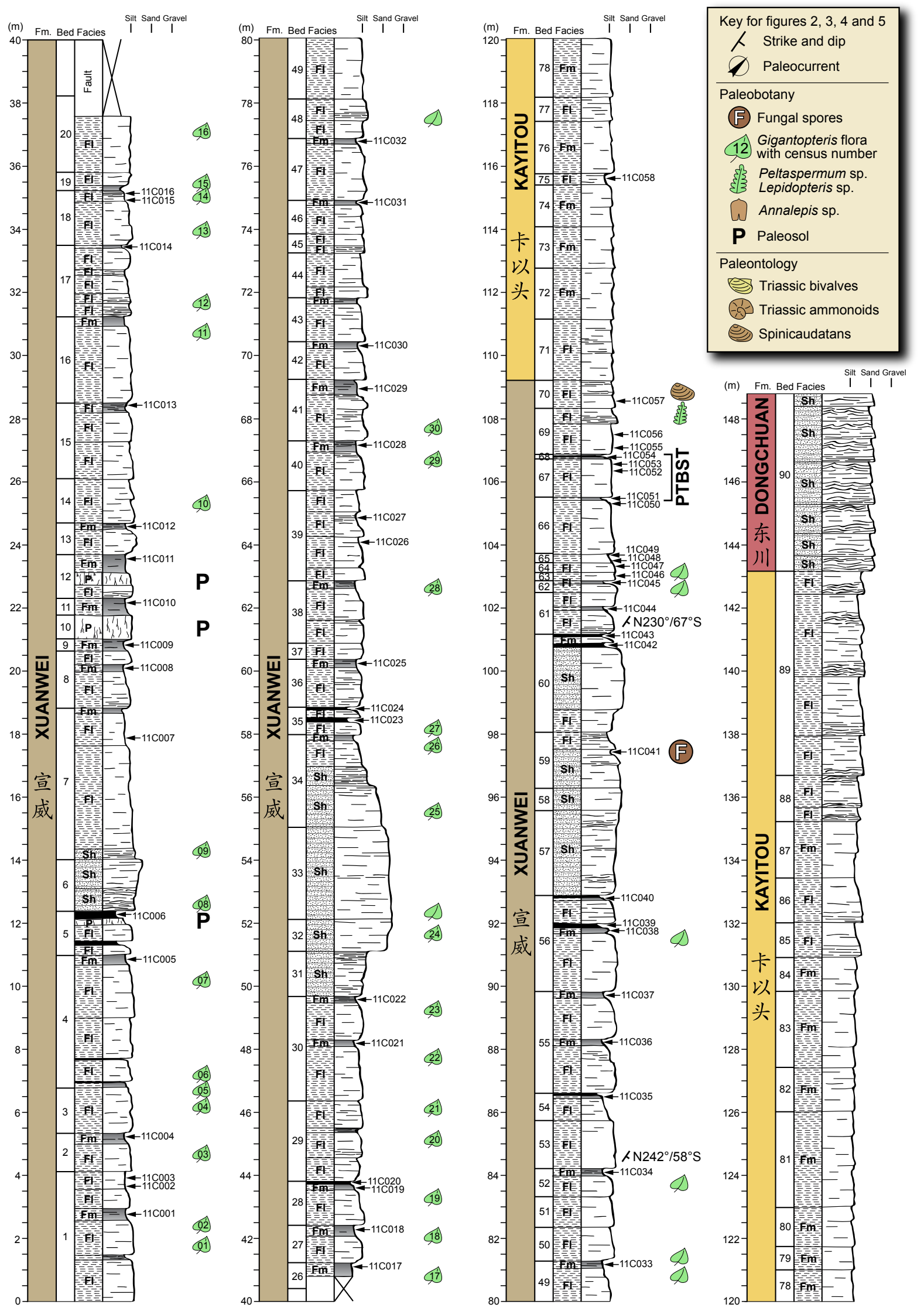

CHAHE 岔河

Fig. 2. Sedimentological log for the Chahe section (see Fig. 1 for location). Position of each palynological/XRF sample and fossil plant census intervals are indicated. 


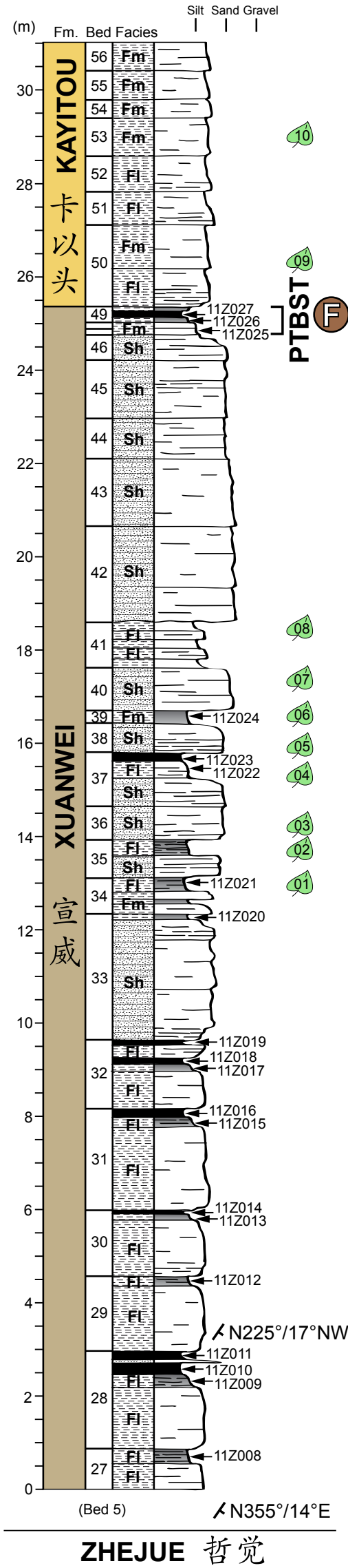

Fig. 3. Sedimentological log for the Zhejue section (see Fig. 1 for location). Position of each palynological/XRF sample and fossil plant census intervals are indicated.

\subsection{Palynofacies analysis}

Palynofacies analysis involved identification of the various organic components; relative abundance calculations of the organic components were based on 300 counts per sample. Classification of palynological matter was tailored for the specific palynofacies of the studied assemblages. As phytoclasts are extremely dominant in most samples, these were subdivided according to color and shape (Supplement Table 1). The following palynofacies elements were distinguished; I, Phytoclasts black (opaque); II, Phytoclasts brown; III, Phytoclasts black shards; IV, Charcoal rounded; V, Charcoal shards; VI, Fungal spores; VII, Fungal Hyphae, and VIII, Miospores (pollen and spores). The slides and residues are deposited with $A B$ and at the China University of Geosciences, Wuhan (China).

\subsection{X-ray fluorescence}

Analyses of major elements were conducted in the laboratory at the Department of Geology, Lund University, using a Thermo Scientific Niton XL3t GOLDD + portable XRF analyzer. Samples were powdered, and one cubic centimeter conditioned into plastic cells equipped with an interchangeable $4 \mu \mathrm{m}$ polypropylene film window. A series of four measurements were performed for each sample and averaged, with anomalous readings, if occurring, removed from the dataset (Supplement Table 2). Accuracy and drift of the absolute concentration readings were verified by regularly measuring a standard calibration sample. Data exploration was performed by principal component analysis (PCA) using standardized variables for emphasizing trends in the variations of trace elements having concentration several orders of magnitude lower than major elements.

\section{Results}

\subsection{The Xuanwei Formation}

The Xuanwei Formation is exposed at all four studied sections and comprises light-colored tan and grey siltstones alternating with sandstone units (Fig. 6A). The rocks are highly fractured, generally hampering the identification of small sedimentary features within the siltstone and mudstone facies, and several small, normal and reverse faults were identified. The bedding is sub-vertical at Chahe $\left(58-67^{\circ}\right)$ and sub-horizontal at Zhejue, Jiucaichong and Mide $\left(14-22^{\circ}\right)$, with variable strike in each section.

The maximum measured thickness of the Xuanwei Formation is at the Chahe section where it reaches $109 \mathrm{~m}$, although the basal part was not exposed. Strike and dip are consistent (N242, $58^{\circ} \mathrm{S}$ and $\mathrm{N} 230^{\circ}, 67^{\circ} \mathrm{S}$; Fig. 2). At the Zhejue section, the Xuanwei Formation is split into two compartments delineated at the base of Bed 27 (Fig. 3). This is indicated by a different strike and dip (N355 , $\left.14^{\circ} \mathrm{E}\right)$ measured for the lower compartment compared to the upper compartment $\left(\mathrm{N} 225^{\circ}, 17^{\circ} \mathrm{NW}\right)$. This represents a $85^{\circ}$ angle difference between compartments, and because of the lack of continuity only the top part was measured. At the Jicuai section, $46 \mathrm{~m}$ of the Xuanwei Formation are exposed with strike and dip measured at $\mathrm{N} 95^{\circ}, 18^{\circ} \mathrm{N}$ and $\mathrm{N} 65^{\circ}, 14^{\circ} \mathrm{S}$ (Fig. 4). At the Mide section only four meters of the Xuanwei Formation are exposed with strike and dip measured at $\mathrm{N} 10^{\circ}, 22^{\circ} \mathrm{NW}$ (Fig. 5).

\subsubsection{Sedimentological analysis}

The Xuanwei Formation comprises six main facies of terrigenous sandstones, siltstones, mudstones and paleosols (Table 1). 


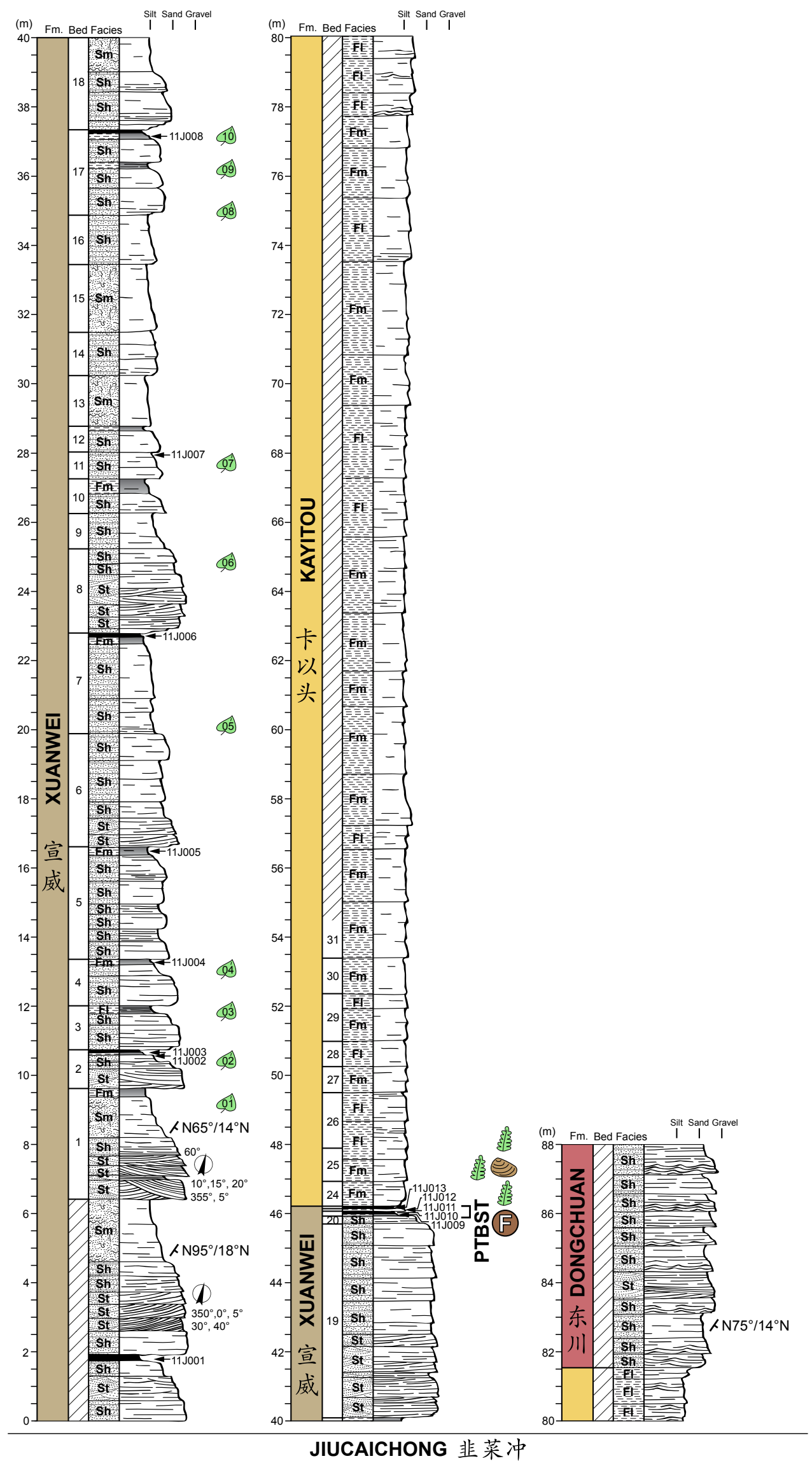

Fig. 4. Sedimentological $\log$ for the Jiucaichong section (see Fig. 1 for location). Paleocurrent directions are indicated where measured, as well as the position of each palynological/XRF sample and fossil plant census intervals. 


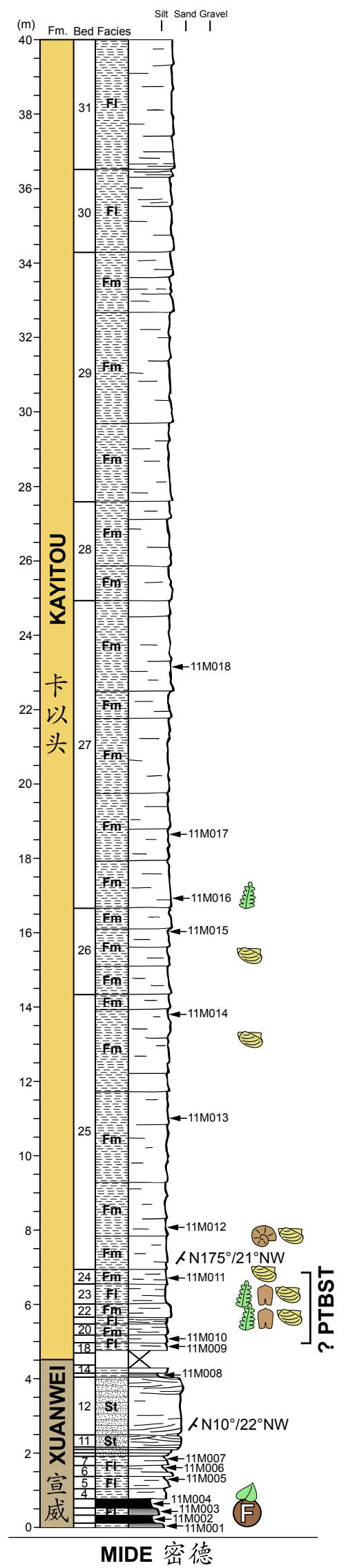

Fig. 5. Sedimentological log for the Mide section (see Fig. 1 for location). Position of each palynological/XRF samples and occurrence of plant fossils are indicated.
The Fl and Fm facies (Table 1, Fig. 6B) are dominant throughout the formation and are represented by $0.1-2$-meter-thick units. They comprise homogeneous siltstones to silty-mudstones, crudely laminated with sub-centimeter-scale sets (Fl facies, Table 1, Fig. $6 \mathrm{~B}$ and $\mathrm{C}$ ) or more rarely, massive to crudely laminated and heterolithic packages (Fm facies, Table 1, Fig. 6B). Due to fracturing, few sedimentary structures were observed, with the exception of some current ripples. The color of the sediments ranges from brown, tan, to organic-rich grey and dark grey facies. Several 540 -cm-thick units of black organic-rich beds were observed (Fig. 6C). They are sometimes referred to as "coal facies" but they contain a significant proportion of terrigenous silica $(13-37 \% \mathrm{Si}$, Supplement Table 2). The Fm facies is interpreted to signify deposition within calm aqueous environments and the Fl facies to represent overbank or waning flood deposits (Miall, 1978; Einsele, 2000).

Coarser lithologies correspond to three distinct sandstones facies; the most common being the Sh facies (Table 1, Fig. 6B and C), which occurs as 0.5-2-meter-thick units with sharp boundaries. The lithology chiefly comprises medium to coarse-grained sandstone showing centimetric to multi-centimetric horizontal laminations and sporadic small scale current ripples. Deposition of the Sh facies corresponds to tractive current or repeated sediment discharges within aqueous environments (Miall, 1978; Einsele, 2000).

The St facies (Table 1, Fig. 6D) occurs in 0.2-1-meter-thick units, and is composed of fine to coarse-grained sandstones with 3D mega ripples. Typical bedforms are comprised between $20-70 \mathrm{~cm}$ high and $50-130 \mathrm{~cm}$ long, with centimetric laminations. The St facies is most common at the Jiucaichong section. Eleven paleocurrent measurements were taken from the trough cross-bedded sandstone unit at the base of the Jiucaichong section (Fig. 4), giving a consistently northward flow direction. Deposition of the St facies corresponds to fluvial channel bedforms.

The Sm facies (Table 1), occurs as 0.5-2-meter-thick units of massive, structureless, silty sandstones to coarse-grained sandstones with sharp boundaries. The $\mathrm{Sm}$ facies corresponds to either deposition from turbulent suspension with insufficient time for bedform development (Lowe, 1982), subaerial hyperconcentrated flows, or subaqueous high-density turbidity currents (Ghibaudo, 1992).

Our observations of the sedimentary successions revealed no "lentoid sandstone" (Zhang et al., 2006) or "lenticular sandstone" (Peng et al., 2006) later reinterpreted as "wedge shaped cross-beddings" (Yin et al., 2007). The sandstone units do not appear to be lenticular (indicating erosional channeling) at the scale of the outcrop. However, modern nodular weathering and fracturing of the sandstone units are extensive.

Paleosols (P facies, Table 1, Fig. 6E) are evident within red silty mudstone facies with no visible primary sedimentary structures. Soil formation is indicated by the presence of very thin vertical rhizoliths, which do not exceed $3 \mathrm{~mm}$ in diameter and 5-10-cm-long. They are visible as white protruding filaments within the red matrix (Fig. 6E). P facies is developed in 20-50-cm-thick units evident only at three stratigraphical positions in the lower part of the Chahe section (Beds 5, 10, 12). P facies is interpreted as an Entisol (immature paleosol with little or no evidence of pedogenic horizons). Indirect evidence of soil formation is indicated throughout the Xuanwei Formation by the presence of Stigmaria sp. rhizomes preserved within some of the fossil plant associations.

The top of the Xuanwei Formation is usually marked by the occurrence of a greenish-grey claystone layer at Bed 68 (Chahe) and Bed 49 (Zhejue), and we were able to locate it at Bed 21a of the Jiucaichong section (Fig. 6F). This so called "eventostratigraphic clay" is part of the upper PTBST complex (Peng et al., 2005). 
Table 1

Description of the main sedimentological facies and associated abbreviations.

\begin{tabular}{|c|c|c|c|}
\hline Code & Facies & Description & Interpretation \\
\hline \multicolumn{4}{|c|}{ Xuanwei Fm. } \\
\hline Sh & $\begin{array}{l}\text { Horizontally stratified } \\
\text { sandstone }\end{array}$ & $\begin{array}{l}\text { Fine- to coarse-grained tan to brown sandstone, with faint horizontal } \\
\text { laminations and occasional erosive base }\end{array}$ & Fluvial sand-sheet deposits \\
\hline St & $\begin{array}{l}\text { Trough cross-bedded } \\
\text { sandstone }\end{array}$ & $\begin{array}{l}\text { Fine- to coarse-grained tan to brown sandstone, with 3D megaripples and } \\
\text { occasionally erosive base }\end{array}$ & $\begin{array}{l}\text { Sinuous-crested or linguoid bedform, braided river } \\
\text { deposits }\end{array}$ \\
\hline Sm & Massive sandstone & Fine- to coarse-grained sandstone, with no apparent lamination & Subaqueous high-density turbidity current \\
\hline $\mathrm{Fl}$ & Laminated mudstone & Laminated siltstone to silty mudstone, greenish-grey to dark grey color & Deposition from suspension, shallow lake or floodplain \\
\hline Fm & Massive mudstone & $\begin{array}{l}\text { Massive siltstone to silty mudstone with little or no apparent lamination, } \\
\text { greenish-grey to dark grey color. Unit average thickness } 5 \mathrm{~cm}\end{array}$ & Deposition from suspension, floodplain \\
\hline $\mathrm{P}$ & Paleosol & Red siltstone with visible rhizoliths & Paleosol \\
\hline \multicolumn{4}{|c|}{ Kayitou Fm. } \\
\hline $\mathrm{Fl}$ & Laminated mudstone & Laminated siltstone to silty mudstone, yellow mustard color & $\begin{array}{l}\text { Deposition from suspension, permanently flooded } \\
\text { with shallow water }\end{array}$ \\
\hline Fm & Massive mudstone & $\begin{array}{l}\text { Massive siltstone to silty mudstone with no apparent lamination, yellow } \\
\text { mustard color }\end{array}$ & $\begin{array}{l}\text { Deposition from suspension, permanently flooded } \\
\text { with shallow water }\end{array}$ \\
\hline \multicolumn{4}{|c|}{ Dongchuan Fm. } \\
\hline Sh & $\begin{array}{l}\text { Horizontally stratified } \\
\text { sandstone }\end{array}$ & $\begin{array}{l}\text { Fine- to medium-grained purple-red sandstone, with well-defined } \\
\text { horizontal laminations and non-erosive base. Current ripples common at } \\
\text { bed top }\end{array}$ & Fluvial sand-sheet deposits \\
\hline St & $\begin{array}{l}\text { Trough cross-bedded } \\
\text { sandstone }\end{array}$ & Fine- to coarse-grained purple-red sandstone, with 3D megaripples & $\begin{array}{l}\text { Sinuous crested or linguoid bedform, braided river } \\
\text { deposits }\end{array}$ \\
\hline
\end{tabular}

\subsubsection{Paleobotany}

The Xuanwei Formation is very rich in plant fossils preserved as large compressions (Fig. 7C). They represent the typical Late Permian Gigantopteris flora. This assemblage was extensively described by Yu (2008). The floral assemblages are dominated by Cordaitales (Cordaites sp.) and pteridosperms (Gigantopteris dictyophylloides, Gigantonoclea guizhouensis, G. nicotianaefolia, G. plumosa, G. hallei, Compsopteris sp., Neuropteris sp., Taeniopteris sp.), with secondary occurrence of equisetales (Lobatannularia heinanensis, L. cathaysiana, L. multifolia, Annularia pingloensis, A. shirakii, Paracalamites stenocostatus), noeggerathiales (Tingia sp.), lepidodendrales (Lepidodendron sp.), ginkgoales (Ginkgoites sp.) and filicales (Pecopteris sp., Fascipteris sp.). Among these, Lobatanularia (Fig. 7D) and gigantopterids (Fig. 7E) represents typical elements of the Cathaysian paleobiogeographic province. No conifers were found. Several Stigmaria (Fig. 7F) occur among the plant compressions. Stigmaria is more abundant in the middle part of the Chahe section, between Beds 26 and 35. Six hundred and two fossil plant specimens from the Chahe, Zhejue and Jiucaichong sections were identified, mainly to genus level (Table 2). Identification of the specimens has been conducted according to Yu (2008). Plant fossils occur most commonly in the laminated silty sandstone ( $\mathrm{Sh}$ ) facies, within the phase of decreasing water flow regime just before deposition of the mudstone and organic-rich units (Fm facies). As such, they indicate transport and accumulation in shallow, slow-moving water.

The fossil plant assemblages served as a tool for paleoenvironmental categorization based on taxonomical composition, preservational mode and taphonomy. We also conducted a detailed field census of the plants in the productive beds at the Chahe section where 475 specimens were counted (Table 2). This dataset covers a large portion of the Xuanwei Formation and provides an estimate of diversity through the latest Permian, but it does not cover the PTB. Variation in diversity across the PTB has been documented from the same locality, but without corrections over variations on sample size (Zhang et al., 2006; Peng et al., 2006; Yin et al., 2007; Yu et al., 2007, 2008, 2010; Peng and Shi, 2009). In this study, statistical correction methods, such as rarefaction, were used in order to compensate for variations in sample size (Gotelli and Colwell, 2001; Colwell et al., 2004).

Our new data is best resolved at the Chahe section, so statistical data on variations in diversity is only evaluated for the plant fossils from this section. Given the relatively low number of counted specimens, a sliding window data binning was performed for each six consecutive census intervals. Individual sample rarefaction was applied on each bin using the software package PAST using $n=40$ and $n=80$ specimens. Two different rarefied values were used because the lower part of the Xuanwei Formation was more thoroughly sampled. Hence the $n=80$ curve best describes the diversity in the lower part whereas the $n=40$ curve includes data bins in the upper part that could not reach the minimum of 80 required specimens. Our results show that assemblages from Beds 1 to 40 vary in diversity, albeit the average diversity remains fairly consistent at around six taxa recovered per 40 specimens (Fig. 8). A drop in diversity is evident around Bed 29, associated with the onset of a thick sandstone unit indicating flash discharge (Beds 32, 33 and 34, Section 4.1.1).

\subsubsection{Palynology}

Palynomorphs were recovered only from the Xuanwei Formation where they are rare but relatively well preserved and dark colored, denoting an early grade of thermal maturation. The assemblages are all dominated by spores including a wide variety of both trilete (Fig. 9 and 1-21) and monolete forms (Fig. 9 and 2229). Several larger $>50 \mu \mathrm{m}$ ornamented spores were identified in samples 11Z006, 11C045, 11J004, and more abundantly in sample 11J012 (Fig. 9). Pollen grains are scarce, and only three specimens were recorded (Fig. 9 and 30-32). They are represented by nontaeniate, bisaccate pollen grains, produced by pteridosperms (Vesicaspora sp.), conifers (Klausipollenites sp.), and caytoniales (Vitreisporites pallidus).

Additionally, freshwater algal cysts, mainly Chomotriletes sp. (Fig. 9, 33 and 34) were encountered in sample 11C023. Many other, very small $\sim 15 \mu \mathrm{m}$ diameter, circular, thin-walled inaperturate palynomorphs may also be related to algae. This indicates that the accumulation of organic matter in the dark, organic rich "coal seams" did not take place within peat-swamp terrestrial environments but rather in lacustrine settings.

At the Mide section, acritarchs (Fig. 9, 35 and 36) and a possible foraminiferal organic lining (Fig. 9 and 37) were recovered from the palynological assemblages of the uppermost Xuanwei Formation (Samples 11M002 and 11M004). They indicate that marine influence began just before the deposition of the Kayitou Formation.

Fungal remains occur close to the top of the Xuanwei Formation in samples from all four sections. They represent a wide range of spores and hyphae (Fig. 9 and 38-53). The recovery is low but their 
Table 2

Field census of the plant fossils occurring at Chahe, Zhejue and Jiucaichong. The census number is referring to positions indicated on each sedimentological logs (Figs. 2-4).

\begin{tabular}{|c|c|c|c|c|c|c|c|c|c|c|c|c|c|c|c|c|c|c|c|}
\hline Section & $\begin{array}{l}\text { Census } \\
\text { number }\end{array}$ & Bed & 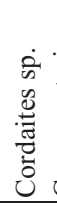 & 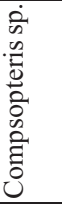 & 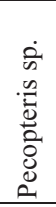 & 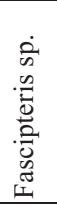 & $\begin{array}{l}\dot{2} \\
\text { n } \\
.0 \\
0 \\
0 \\
0 \\
0 \\
0 \\
0 \\
0\end{array}$ & 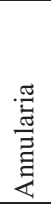 & $\stackrel{\frac{\pi}{60}}{\stackrel{0}{\Xi}}$ & 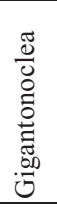 & 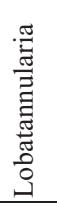 & 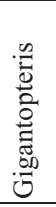 & 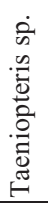 & $\begin{array}{l}0 \\
0 \\
0 \\
0 \\
0 \\
0 \\
0 \\
0 \\
0 \\
0 \\
\end{array}$ & 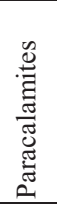 & 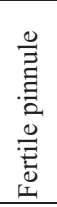 & 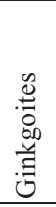 & 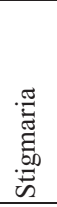 & $\begin{array}{l}0 \\
\stackrel{n}{0} \\
0\end{array}$ \\
\hline \multirow[t]{30}{*}{ Chahe } & 1 & 1 & 40 & 25 & 2 & 4 & & & & & & & & & & & & & \\
\hline & 2 & 1 & & 1 & & & & & & & & & & & & & & 3 & \\
\hline & 3 & 2 & 26 & 13 & & & & 1 & 1 & 1 & & & & & & & & & \\
\hline & 4 & 3 & 10 & 10 & & & & & & & 1 & & & & & & & & \\
\hline & 5 & 3 & 2 & 20 & & & & & & & & & & & & & & & \\
\hline & 6 & 4 & 13 & 8 & 2 & & & & & & & & & & & & & & \\
\hline & 7 & 4 & & 6 & 2 & & & & & & 6 & 1 & & & & 1 & & & \\
\hline & 8 & 6 & 8 & 1 & 3 & & & & & & 2 & 1 & & & & & & 1 & \\
\hline & 9 & 7 & 14 & 19 & 9 & 1 & 4 & & & 1 & & & 3 & & & & & & \\
\hline & 10 & 14 & 3 & & 1 & & & & & & & 1 & & & & & & & \\
\hline & 11 & 16 & 15 & & & & & & & & & 3 & & & & & & 1 & \\
\hline & 12 & 17 & 8 & 4 & 1 & & & & & & 3 & 4 & & & & & & & + \\
\hline & 13 & 18 & 4 & & 1 & & & & & & & & & & & & & & \\
\hline & 14 & 18 & 3 & & & & & & & & 1 & & & 4 & & & & 1 & \\
\hline & 15 & 19 & 15 & 17 & 1 & & & & & & 1 & 1 & & & & & & & \\
\hline & 16 & 20 & 18 & & & & & & & & 3 & 2 & & & 1 & & & & \\
\hline & 17 & 26 & & & & & & & & & & & & & & & & 4 & \\
\hline & 18 & 27 & & & & & & & & & & & & & & & & 1 & \\
\hline & 19 & 28 & 12 & 1 & & & & & & 4 & & & & & & & & & \\
\hline & 20 & 29 & 9 & & & & & & & 1 & & & & & & & & & + \\
\hline & 21 & 29 & 4 & & 1 & & & & & 2 & & & & & & & & 3 & \\
\hline & 22 & 30 & & & & & & & & & & & & & & & & 5 & \\
\hline & 23 & 30 & & & & & & & & & & & & & & & & 3 & \\
\hline & 24 & 32 & 9 & & 2 & & & & & & 1 & & & & & & 1 & & \\
\hline & 25 & 34 & 5 & & 2 & & & & & & & 1 & 1 & & & & & & \\
\hline & 26 & 34 & 1 & & & & & & & & & & & & & & & 4 & \\
\hline & 27 & 35 & & & & & & & & & & & & & & & & 4 & \\
\hline & 28 & 38 & 4 & & & & & & & & & 1 & & & & & & 1 & + \\
\hline & 29 & 40 & 4 & & 1 & & & & & & & & & & & & & & \\
\hline & 30 & 41 & & & & & & & & & & & & & & & & & + \\
\hline Total: 475 & & & 227 & 125 & 28 & 5 & 4 & 1 & 1 & 9 & 18 & 15 & 4 & 4 & 1 & 1 & 1 & 31 & \\
\hline \multirow[t]{10}{*}{ Jiucaichong } & $\begin{array}{ll}g & 1\end{array}$ & 1 & & & & & & & & & & & & & & & & 2 & + \\
\hline & 2 & 2 & & & & & & & & & & & & & & & & & + \\
\hline & 3 & 3 & & & & & & & & & & & & & 1 & & & 2 & \\
\hline & 4 & 4 & 3 & & 1 & & & & & & & & & & 1 & & & & \\
\hline & 5 & 7 & 3 & & & & & & & & & & & & & & & & \\
\hline & 6 & 8 & 3 & 2 & 1 & & 1 & & & & 2 & & & & & & & & \\
\hline & 7 & 11 & 3 & & 1 & & & & & 2 & 1 & 3 & 1 & & & & & & \\
\hline & 8 & 17 & & & & & & & & & & & & & & & & 1 & + \\
\hline & 9 & 17 & & & & & & & & & & & & & & & & 3 & + \\
\hline & 10 & 17 & & 2 & 4 & 1 & & & & & & 2 & & & & & & 4 & + \\
\hline Total: 50 & & & 12 & 4 & 7 & 1 & 1 & & & 2 & 3 & 5 & 1 & & 2 & & & 12 & \\
\hline \multirow[t]{10}{*}{ Zhejue } & 1 & 34 & & & & & & & & & & & & & & & & 4 & + \\
\hline & 2 & 35 & 6 & & & & & & & & 1 & 2 & & & & & & & \\
\hline & 3 & 36 & 3 & & 3 & & & & & & & 2 & & & & & & & \\
\hline & 4 & 37 & & & & & & & & & & & & & & & & 6 & + \\
\hline & 5 & 38 & 1 & 3 & 3 & & & & & & & 1 & & & & & & & + \\
\hline & 6 & 39 & & & & & & & & & & & & & & & & 6 & + \\
\hline & 7 & 40 & 1 & 1 & 1 & & & & & & & & 1 & & & & & 1 & \\
\hline & 8 & 41 & & & & & & & & & & & & & & & & 10 & \\
\hline & 9 & 50 & 1 & 11 & 1 & & & & & & & 4 & & & & & & & + \\
\hline & 10 & 53 & & & & & & & & & & & & & & & & 4 & \\
\hline Total: 77 & & & 12 & 15 & 8 & & & & & & 1 & 9 & 1 & & & & & 31 & \\
\hline Grand total: & $: 602$ & & 251 & 144 & 43 & 6 & 5 & 1 & 1 & 11 & 22 & 29 & 6 & 4 & 3 & 1 & 1 & 74 & \\
\hline
\end{tabular}



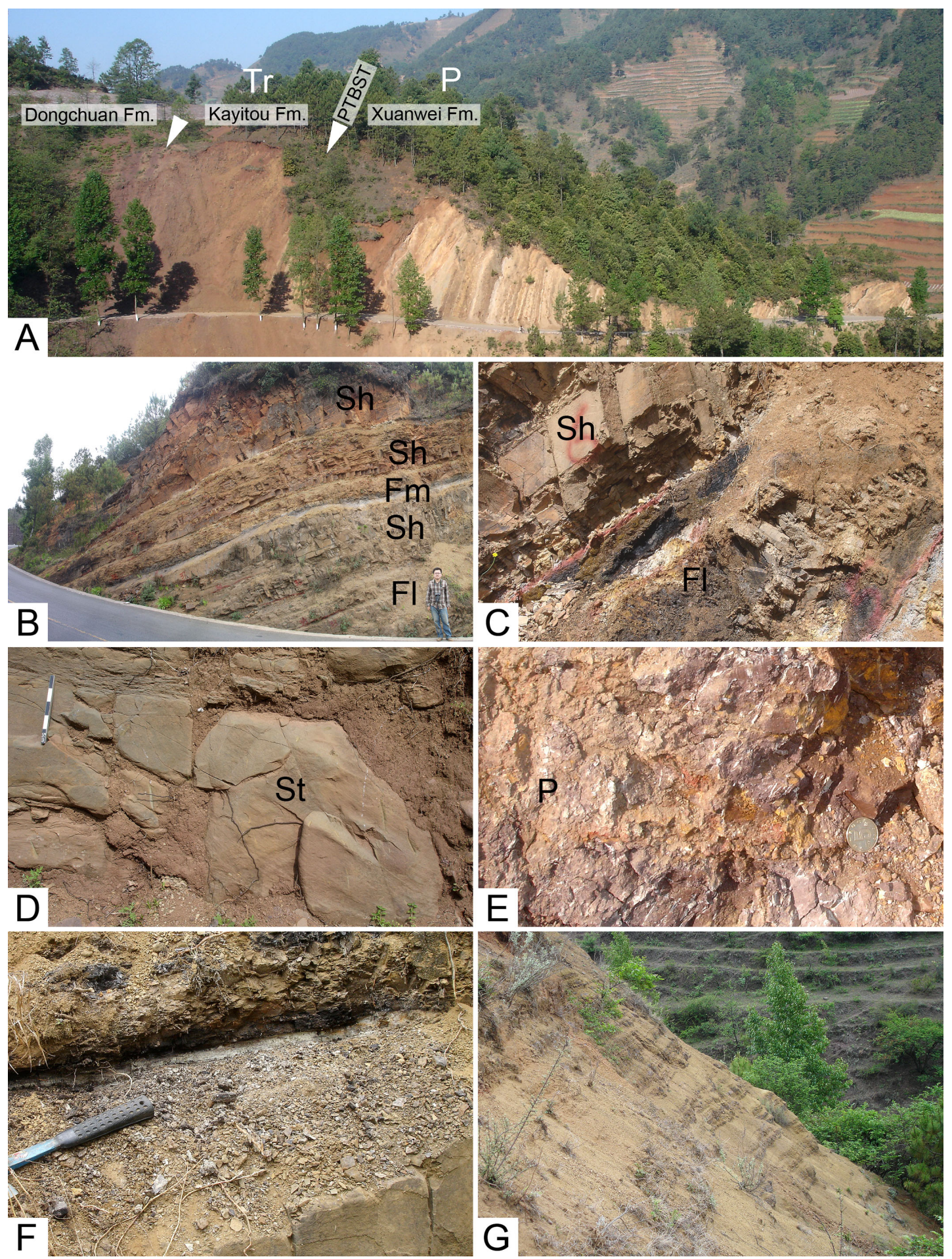

Fig. 6. (A) Exposure of the terrestrial PTB transition at Chahe, western Guizhou. (B) Beds 33-46 within the Xuanwei Formation at the Zhejue section. The sediments of the Xuanwei Formation consist of massive planar bedded sandstone units intercalated with grey silty mudstone units. (C) Dark, organic rich, silty mudstone at the top of Bed 5 , Xuanwei Formation, Chahe section. (D) Cross-bedded sandstone unit within the Xuanwei Formation at the base of Bed 1, Jiucaichong section. (E) Occurrence of paleosol (entisol) within Bed 5, Xuanwei Formation, Chahe section. (F) The top of the Xuanwei Formation and PTBST at Jiucaichong, showing a thin light green bentonite unit (Bed 21a). (G) Typical Kayitou Formation facies of homogeneous silty sandstone at the Jiucaichong section.

relative abundance is close to $100 \%$ in samples in which they occur. At the Zhejue section, multicellular spores occur within sample 11 Z026 (Bed 49a), from the claystone bed representing the uppermost layer of the PTBST. A similar pattern is seen at the Jiucaichong section where the fungal spores occur in samples 11J009 (Bed 21a) within the PTBST upper claystone bed (Fig. 6F) and 11J010 (Bed 21b). At the coastal Mide section, fungal spores occur within the two organic-rich units at the base of the section, within samples 11M002 (Bed 2) and 11M004 (Bed 4). Here, a significant diversity of fungal spores is apparent, including numerous ascospores (Fig. 9 and 39-42). At Chahe, fungi are evidenced, only by the presence of a few hyphae in sample 11C041 (Bed 59), or about $10 \mathrm{~m}$ below the PTBST. Several spores can be attributed to Reduviasporonites (Fig. 9 and 49-51).

\subsubsection{Palynofacies analysis}

All four sections (66 samples) were investigated for palynofacies characterization (Supplement Table 1). Black and brown phyt- 

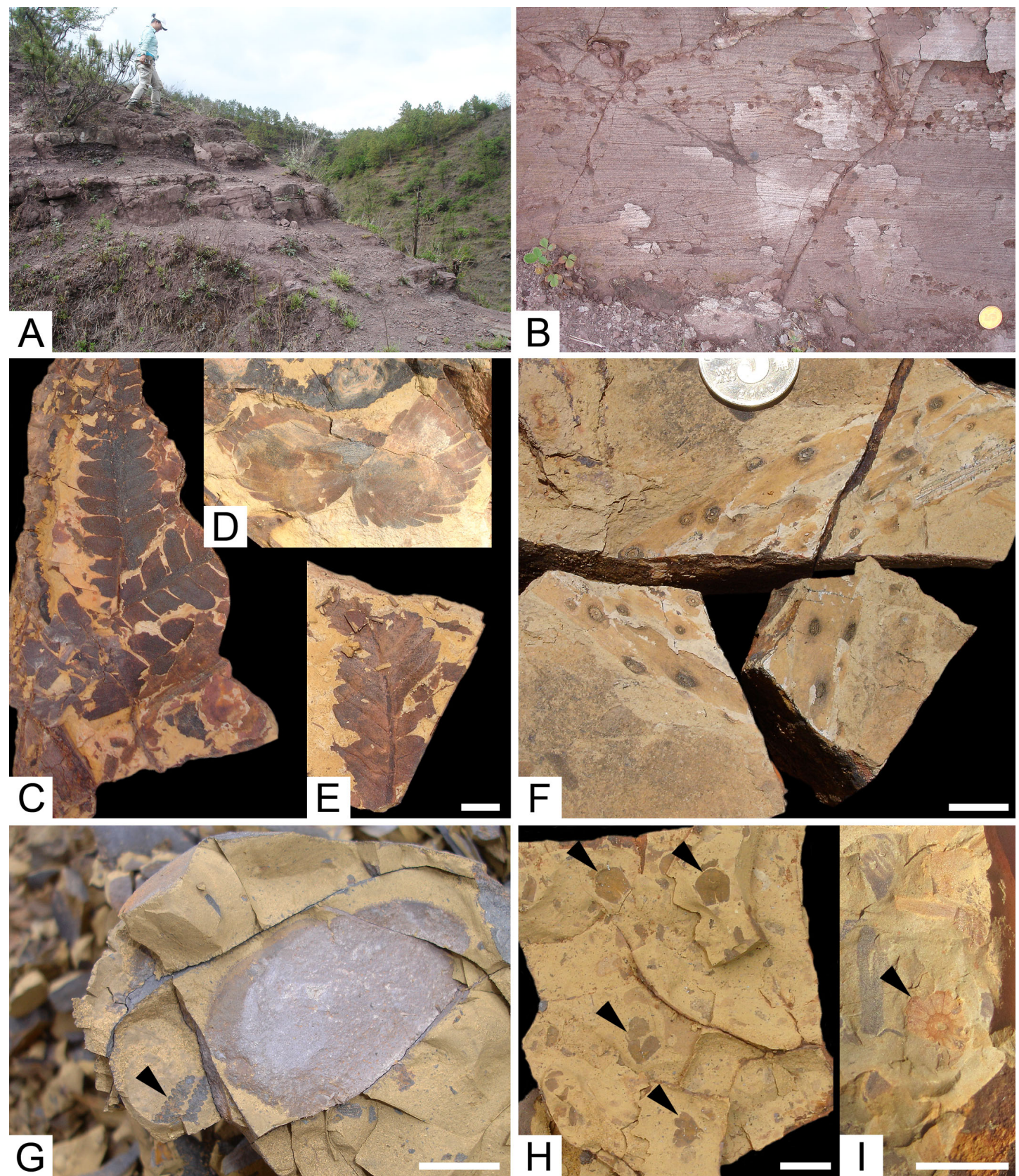

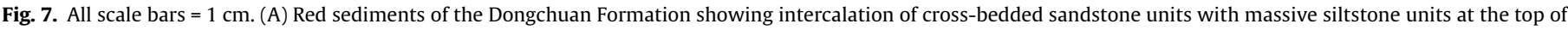

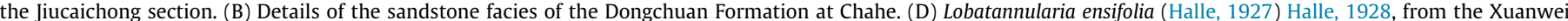

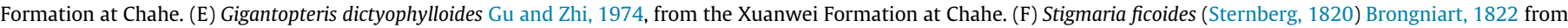

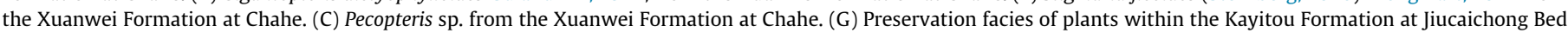

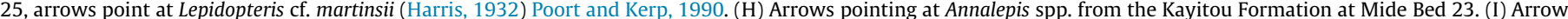
pointing at a Peltaspermum sp. ovuliferous disk found in sediments from the Kayitou Formation at Mide Bed 23.

oclasts are the dominant components in all studied assemblages. Specific signatures of the studied successions include the dearth of amorphous organic matter, high abundance of charcoal and specifically charcoalified wood shards, and fairly high relative abundance of fungal spores at some stratigraphical levels. The recovery of miospores is very low with the exception of four samples (Fig. 10).

The organic matter within the basal parts of all sections (Xuanwei Formation) is dominated by charcoal. Rounded charcoal particles reach a maximum relative abundance of $89 \%$ in the Chahe section, and $97 \%$ in the Zhejue section. Higher in the successions, the organic matter in the Xuanwei Formation is dominated by brown and black phytoclasts. Interestingly, miospores are concentrated in samples within the topmost part of the formation, close to the PTB, reaching up to $18 \%$ of the organic components. Fungal spores generally occur in samples adjacent to the PTB at the top of the Xuanwei Formation.

\subsection{The Kayitou Formation}

The Kayitou Formation is exposed as distinctive mustard yellow silty sandstone units (Fig. 6G) resting conformably on the underlying Xuanwei Formation with a gradational contact spanning 1$3 \mathrm{~m}$. Weathering makes bedding visible on the outcrop surface, but a freshly excavated face shows homogeneous grain size with no obvious variations. The Kayitou Formation is 34-meter-thick at Chahe and 35-meter-thick at Jiucaichong (Figs. 2 and 4). At the coastal Mide section, the Kayitou Formation is much thicker, pos- 


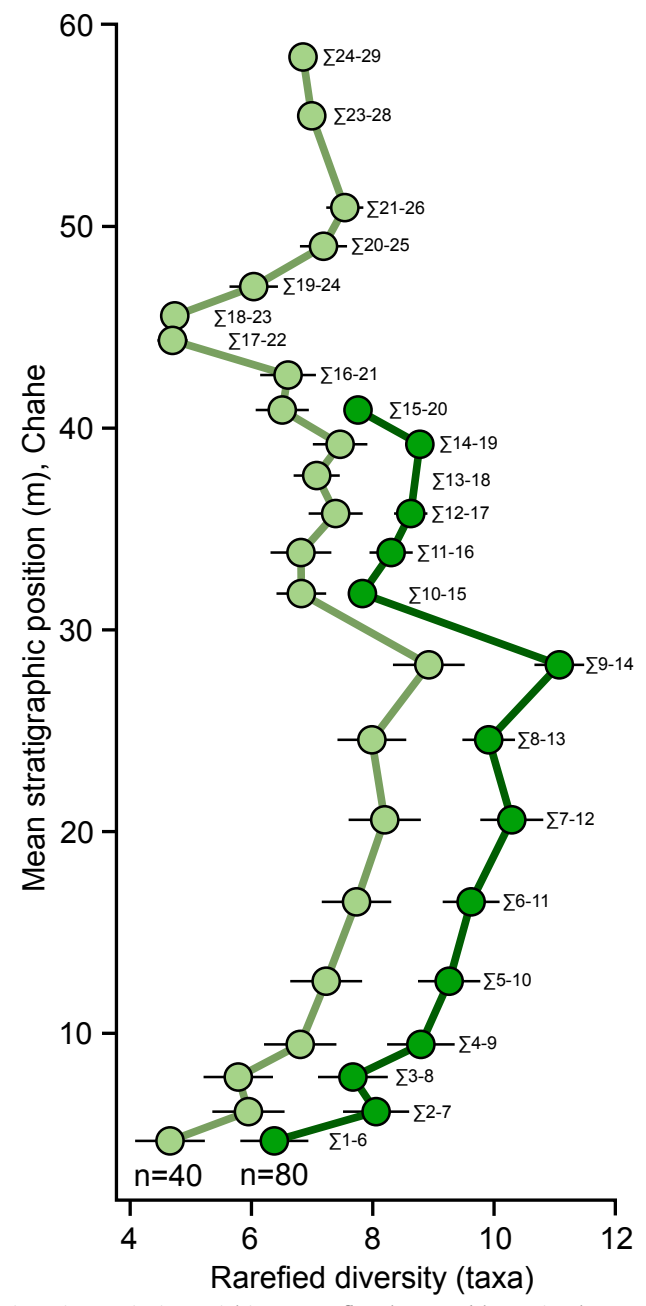

Fig. 8. Diversity variation within macrofloral assemblages in the sampled sections within the Xuanwei Formation sampled at the lower part of the Chahe section. Data from Table 2 was combined using sliding window binning of six consecutive census intervals. The resulting data was rarefied at 40 and 80 specimens to remove sample size variation related bias. Error bars are $95 \%$ confidence intervals.

sibly reaching $60 \mathrm{~m}$ but only the basal $36 \mathrm{~m}$ was measured for this study.

\subsubsection{Sedimentological analysis}

The sediments of the Kayitou Formation are homogeneous and only the Fl and Fm facies (Table 1, Fig. 6G) are represented. The succession comprises $0.1-1$-meter-thick siltstone to silty-sandstone units. The basal part of the formation is dominated by the homogeneous and massive to crudely laminated Fm facies (Table 1). The Fl facies is finely laminated with very well defined sub-centimeter-scale heterolithic sets, and its occurrence increases towards the top of the formation. In association, the upper onethird of the Kayitou Formation is characterized by the occurrence of small-scale current ripples at the base of most Fl units. Both Fl and Fm facies are extremely friable, breaking into small blocks and shards when excavated. The mustard yellow color grades upward into yellowish-green, and the upper third of the formation is generally finely variegated with yellowish-green and purple-red bands increasing in dominance towards the top. The mustard yellow color is especially evident on powdered rocks.

\subsubsection{Paleobotany}

In the Kayitou Formation, plant fossils are found in the lowermost few meters at the Jiucaichong and Mide sections, but they are much more scarce than in the Xuanwei Formation. The preser- vation is also different, as plant fossils consists of scattered, small $(\leqslant 1 \mathrm{~cm})$ comminuted debris (Fig. $7 \mathrm{G})$. New plant taxa appear in the Kayitou Formation, the most significant being Annalepis (Fig. 7H), peltaspermalean foliage (Lepidopteris cf. martinsii, Fig. 7G) and fertile organs (Peltaspermum sp., Fig. 7I). These collectively constitute a distinctive Annalepis-Peltaspermum assemblage. Annalepis is a Triassic lycopsid that relates to Isoetes, with similar growth habit as Pleuromeia (Grauvogel-Stamm and Duringer, 1983; Naugolnykh, 2013). The genus is based on isolated sporophylls that articulate in cones (Meng, 1998; Grauvogel-Stamm and Lugardon, 2001), which closely resemble those of Tomiostrobus (Naugolnykh, 2012).

\subsubsection{Ostracod assemblage}

At the Mide section, marine ostracods have been previously mentioned from the Kayitou Formation in Beds 21 to 26 (e.g. Yu et al., 2010). Recent fieldwork did not recover any ostracods outside Bed 25, which yielded abundant specimens on the surface of cracked siltstones/fine sandstones. Preliminary observations indicate that the recovered assemblage is nearly monogeneric and dominated by Hollinella specimens. Two species were previously reported: Langdaia suboblonga and Hollinella tingi (sic). No Langdaia was observed in our study. Altered and corroded specimens of Hollinella originally characterized by their lobes and frill, are abundant and might have been mistakenly identified as Langdaia in past studies. Hollinella tingi (Patte) has been demonstrated to be restricted to the Early Permian (e.g. Crasquin-Soleau et al., 2004) and its specific characters are not evident from Mide specimens.

\subsection{The Dongchuan Formation}

The Dongchuan Formation is exposed as alternating purple-red siltstone and sandstone units (Fig. 7A) resting conformably on the underlying Kayitou Formation with a gradational contact spanning $\sim 5 \mathrm{~m}$. The Dongchuan Formation is at least $50+$ meter-thick in the study area, the top has not been identified. In the purple-red Dongchuan Formation, no fossil plants were found owing to the oxidizing conditions that destroyed all traces of organic matter.

\subsubsection{Sedimentological analysis}

Two main facies are represented within the Dongchuan Formation, the most common feature being the Sh facies (Table 1, Fig. 7A). The Sh facies occurs as $0.2-1$-meter-thick units of fineto medium-grained sandstone, with horizontal laminations, and common current ripples. Boundaries are usually not erosive. Deposition of the Sh facies corresponds to tractive current or repeated sediment discharges within aqueous environments. The St facies is composed of fine- to medium-grained sandstones with trough cross bedding (Fig. 7B). Increasing occurrence of the St facies is observed towards the top of the formation, as seen from stacked sequences found in an unmeasured part of the Dongchuan Formation at Chahe (Fig. 7B). Deposition of the St facies corresponds to fluvial channel bedforms.

\subsection{X-ray fluorescence}

Results of the XRF analysis of a series of samples from the Xuanwei and Kayitou formations, across the four studied sections show that the chemical composition of the rocks is consistent and that all samples are devoid of $\mathrm{CaCO}_{3}$ (Supplement Table 2). No data clustering appear based on geographical location of sections (Fig. 11), not even for the coastal Mide section at a distance of $170 \mathrm{~km}$ from Chahe, Zhejue and Jiucaichong (Fig. 1), showing that the chemical composition is laterally consistent and not related to geographical location but rather to time of deposition. Three major composition clusters are evident from the principal component 

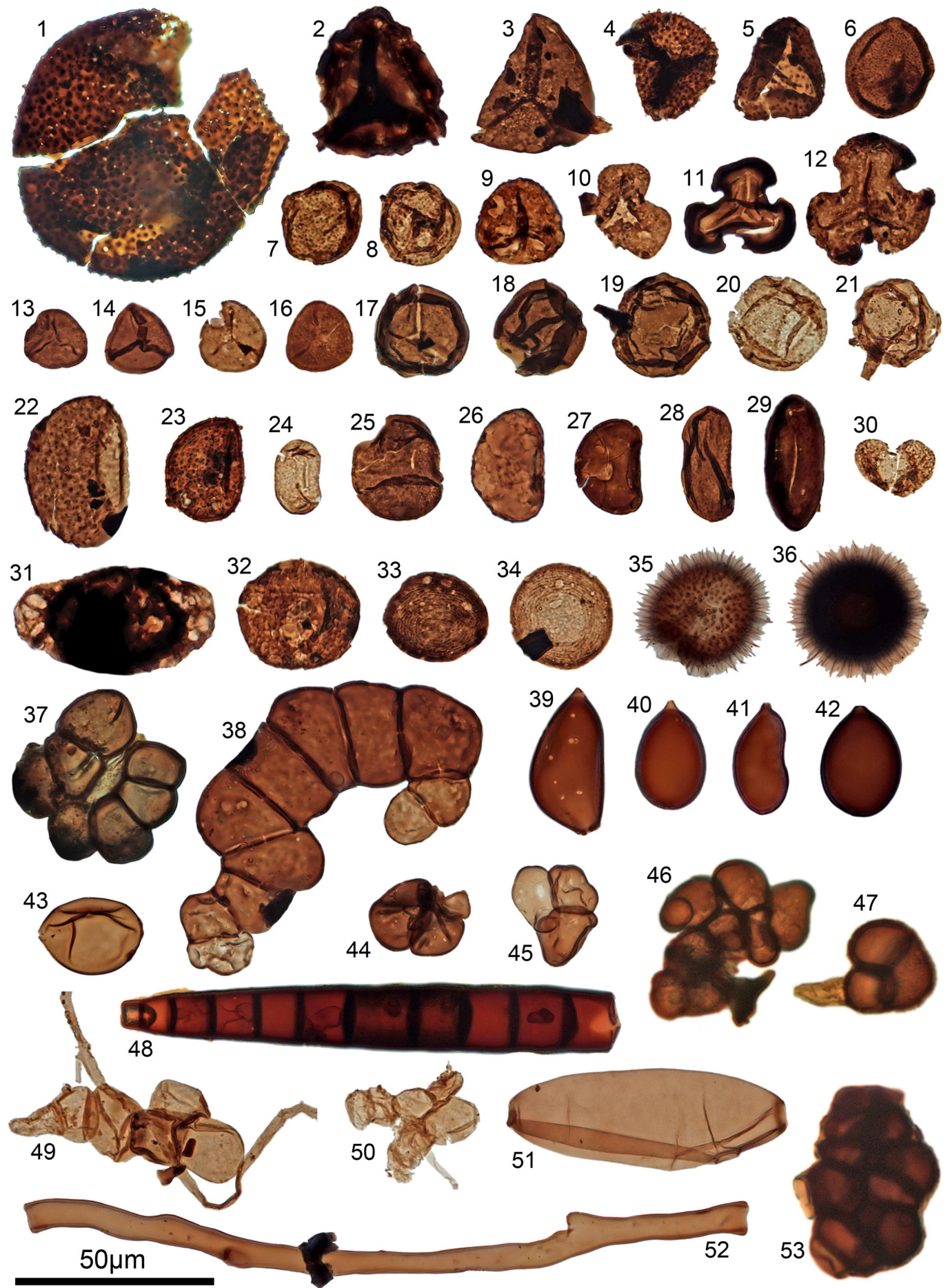

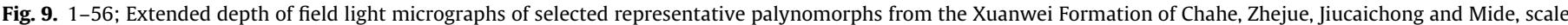

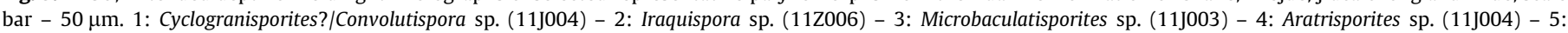

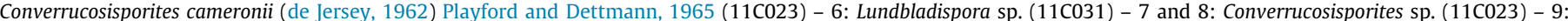

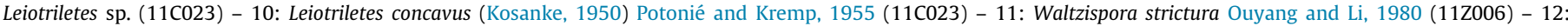

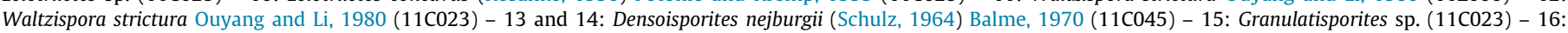

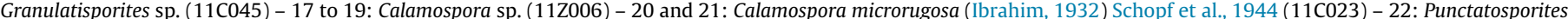

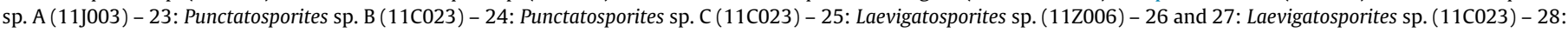

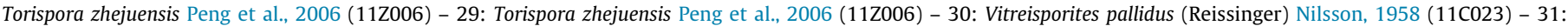

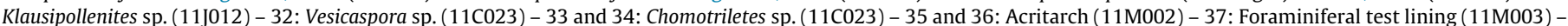

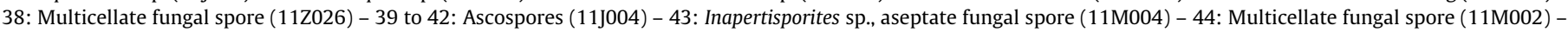

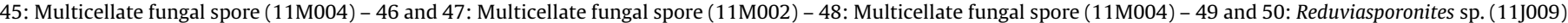
- 51: Reduviasporonites sp. (11M002) - 52: Fungal hyphae (11J009) - 53: Multicellate fungal spore (11J010).

analysis of the XRF data (Fig. 11), two within the Xuanwei Formation and one within the Kayitou Formation. The Xuanwei Formation includes two clusters, the first grouping siliciclastic sediments and the second grouping organic-rich sediments enriched in elements such as S, P, W, Se, Cu, Ca, As. Additionally, the results from the "coal beds" and the other organic-rich samples 


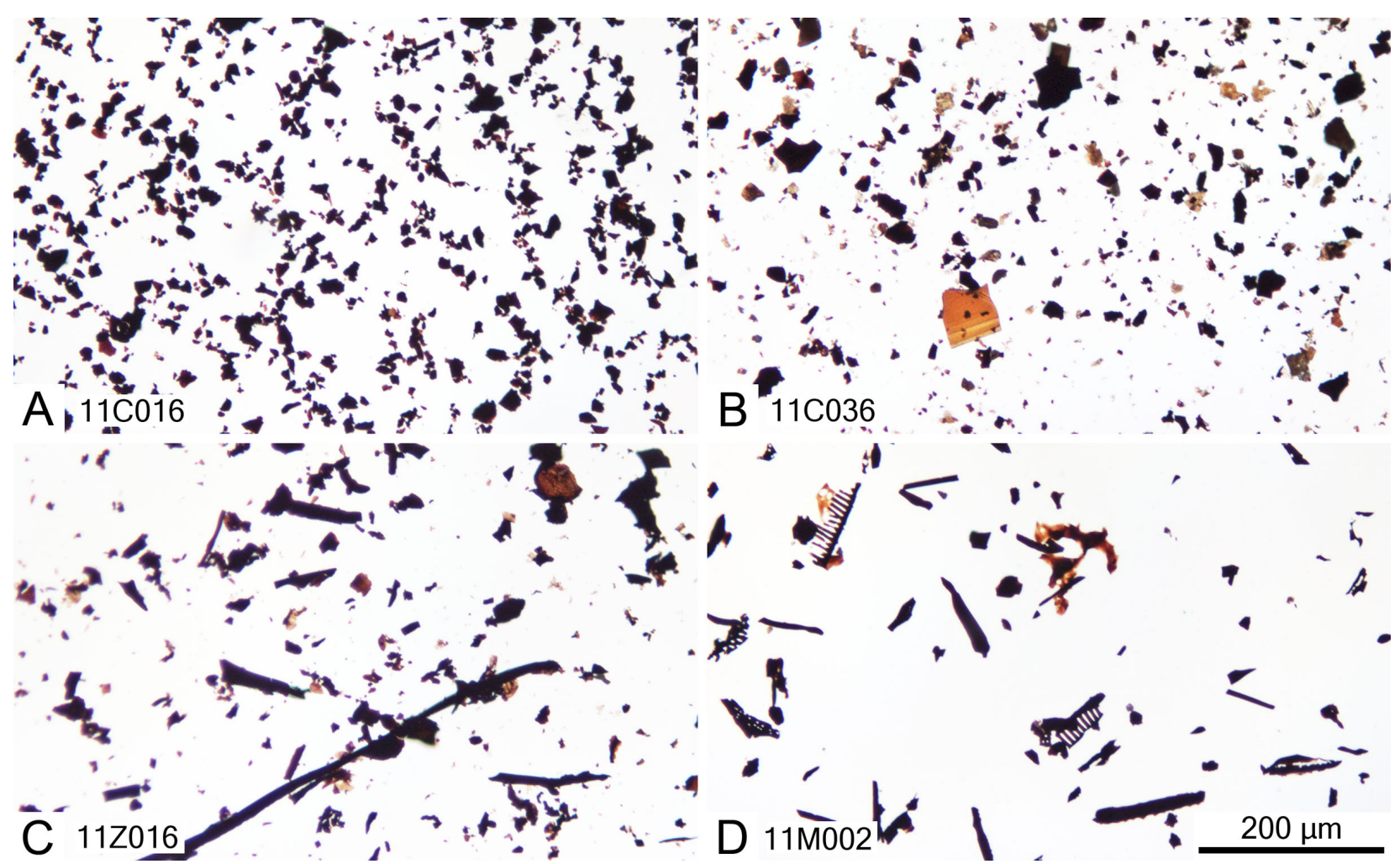

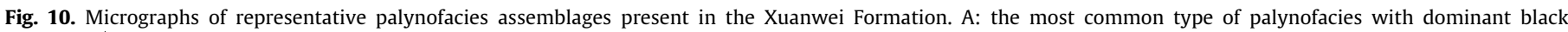

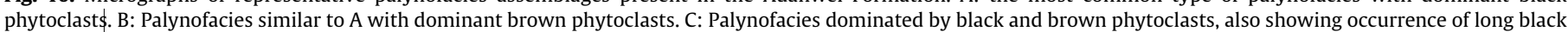

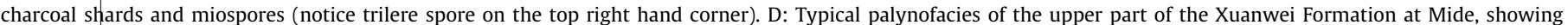
abundant phytoclasts and black charcoal shards (notice the two fern tracheids with scalariform pitting).

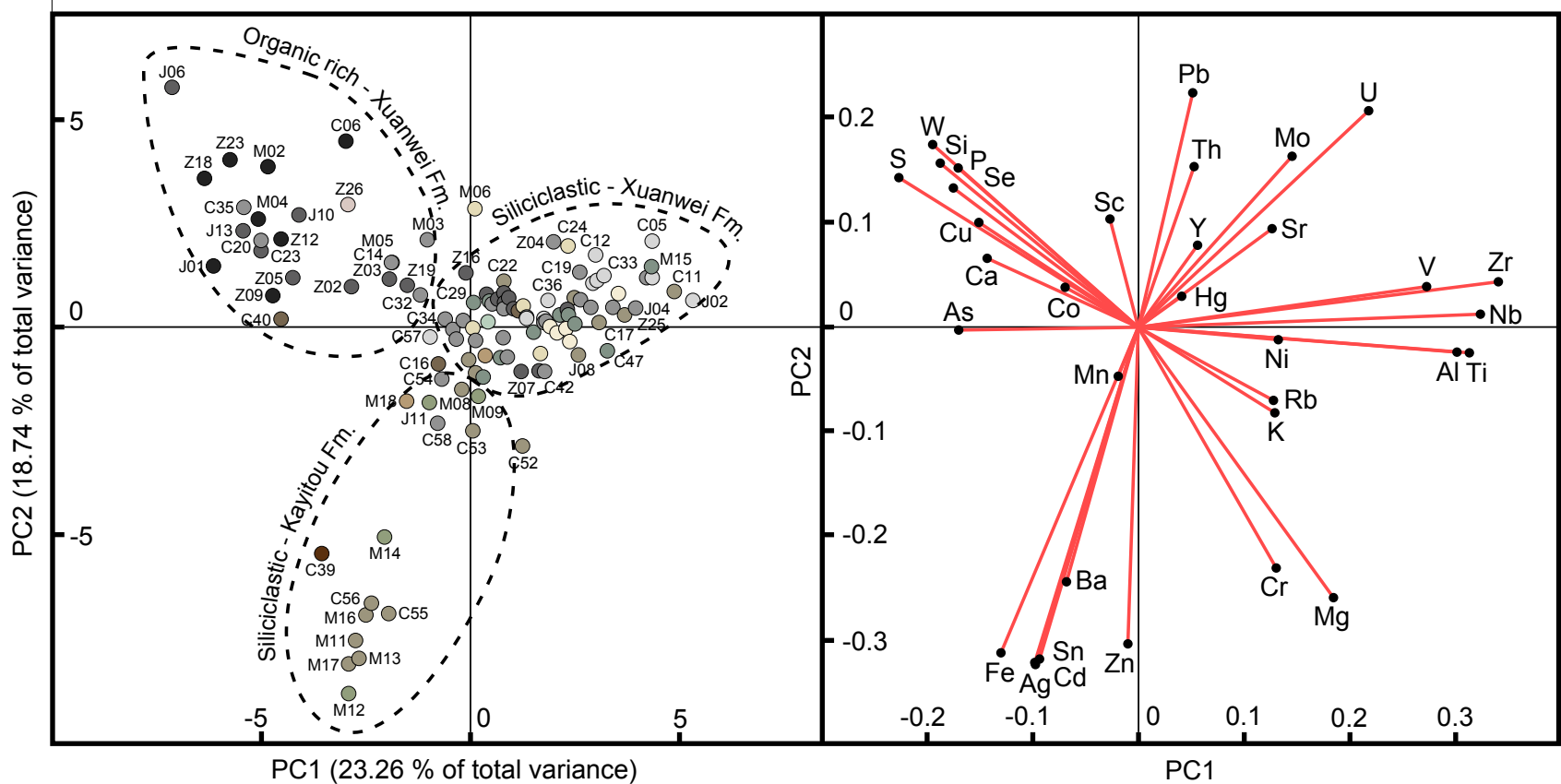

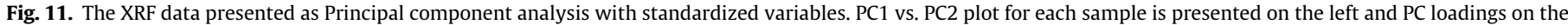
right. Sample names have been shortened e.g. "11C001" corresponds to "C01" in the diagram.

show that they contains a significant proportion of terrigenous silica (from $13 \%$ to $37 \%$ Si, Supplement Table 2 ). These two groups of sediments alternate through the succession. The third cluster encompasses sediments from the Kayitou Formation with enriched proportions of $\mathrm{Fe}, \mathrm{Ba}, \mathrm{Sn}, \mathrm{Ag}$ and $\mathrm{Cd}$. All sediments analyzed were devoid of carbonate, as indicated by the small amount of calcium (Supplement Table 2).

\section{Paleoenvironmental interpretation}

The general evolution of the PTB successions in Guizhou and Yunnan shows a transition from deposits representing terrestrial, nearshore fluvio-lacustrine environments with wetlands to brackish lagoonal and coastal marine environments. Across the four sections, Jiucaichong is the most proximal relative to Chahe and 


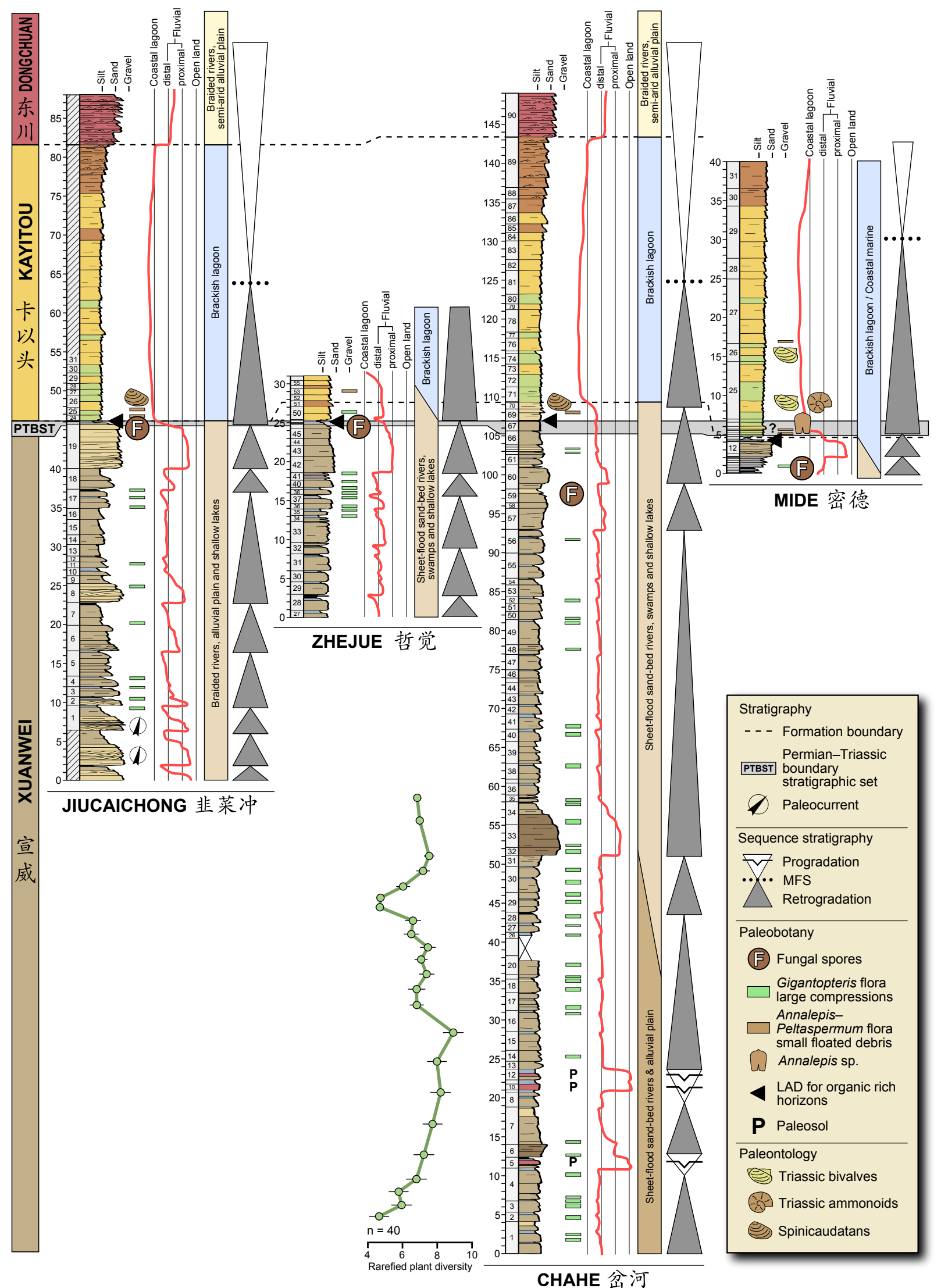

Fig. 12. Correlation of the studied sections, depositional environments and stratigraphical synthesis. 


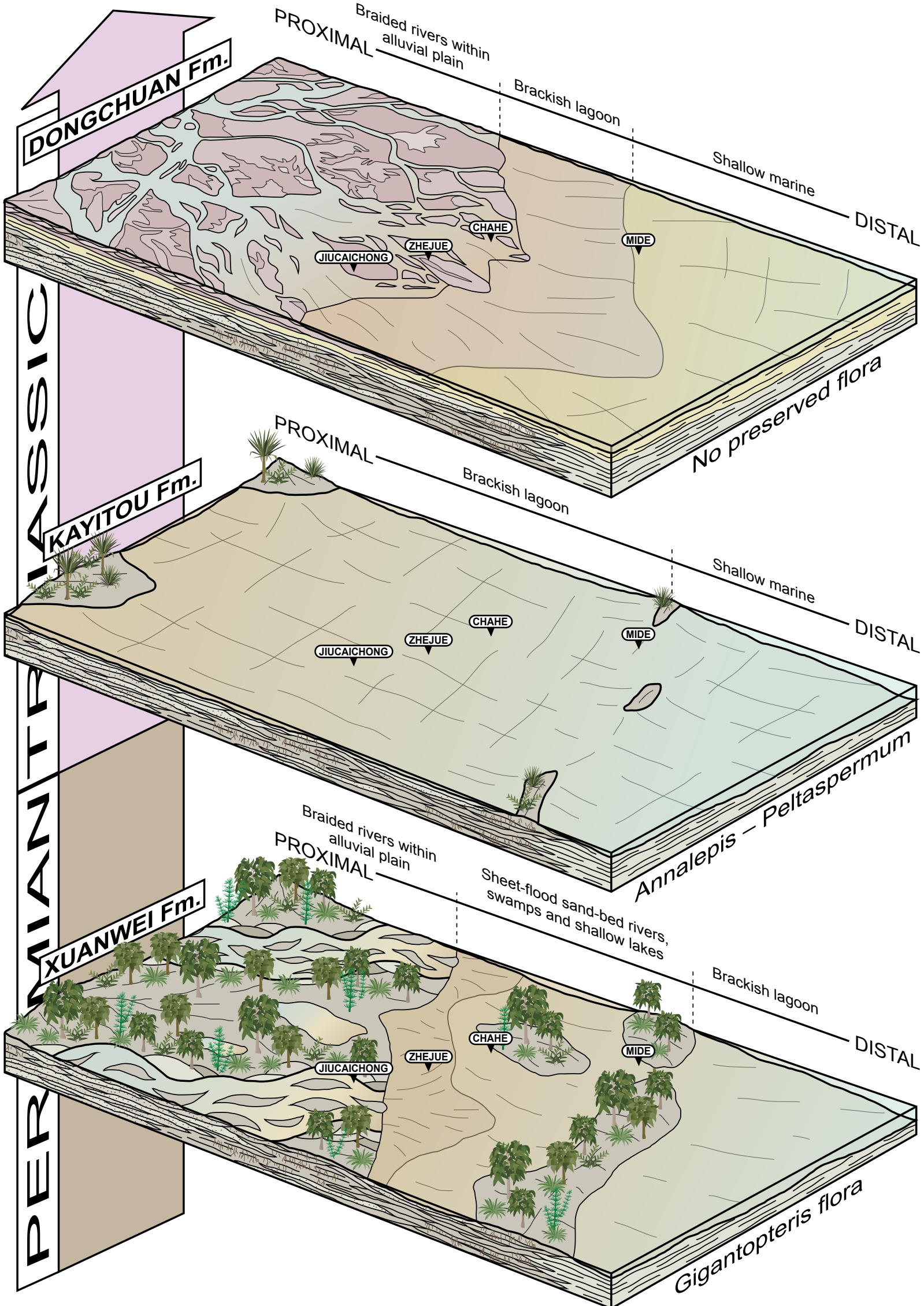

Fig. 13. Block diagrams showing the reconstruction of the depositional environment of the Xuanwei, Kayitou and Dongchuan formations. Position of the four studied sections is indicated relative to the proximal/distal transect. 
Zhejue, showing more fluvial influence and less deposition of fine organic rich sediments (Fig. 6). The occurrence of freshwater algal cysts in these organic-rich facies indicates deposition in a lacustrine environment. Our results show that variations in plant diversity occur within the lowermost $60 \mathrm{~m}$ of the Xuanwei Formation at Chahe, albeit the average diversity is fairly consistent with around six taxa represented amongst 40 specimens (Fig. 9). A drop in diversity is evident around Chahe Bed 29, correlated with a local environmental transition from dry floodplains to wetlands (Fig. 12).

Our sedimentological and paleontological observations contrast with previous interpretations of depositional environments (Zhao, 2003; Yu et al., 2007). The Xuanwei Formation does not represent meandering river systems because no point bar deposits were identified. Rather, it represents wetlands consisting of swamps and shallow lacustrine environments with sheet-flood sand-bed rivers. At the Jiucaichong section, more proximal settings correspond to the occurrence of braided river systems within alluvial plain and shallow lakes (Figs. 12 and 13). The Kayitou Formation does not correspond to lacustrine deposits (Yu et al., 2007), but rather to terrigenous sedimentation from suspension in coastal lagoon environments, as attested by the presence of marine fossils at the Mide section. The occurrence of plant fossils with a marine fauna, as in the Permian of Laos (Bercovici et al., 2012a; Blanchard et al., 2013) and Saudi-Arabia (Berthelin et al., 2004), nevertheless indicates close proximity to the coastline and terrigenous input in the basin. In more proximal settings, such as represented in the Chahe and Zhejue sections, marine influence is not evidenced by any fossils, and the occurrence of spinicaudatans (i.e. conchostracans) at the Jiucaichong and Chahe section would indicate a mainly coastal influence such as a brackish lagoon. The transition between the Xuanwei Formation and the Kayitou Formation is marked by the sharp disappearance of organic matter in the sediments.

\subsection{Xuanwei Formation}

The successions within the Xuanwei Formation were deposited chiefly in a non-marine environment at all sections except Mide, which displays marine influence at the very top of the Xuanwei Formation. A vertical transition from alluvial plain facies to fluvial and lacustrine facies towards the top of the formation is evidenced. Two major depositional environments are represented:

- The first, expressed in the lower part of the Xuanwei Formation (0-40 $\mathrm{m}$ at Chahe), is composed of stacked sequences of Sh and St facies fining upwards to the generally organic-rich $\mathrm{Fl}$ and Fm facies, sometime associated with paleosol development (facies $\mathrm{P}$ or occurrence of Stigmaria sp.). The repeated occurrence of these paleosols is indicative of an alluvial floodplain. These stacked genetic sequences range from 0.5 to 4-meter-thick and are interpreted as flash discharges leading to the deposition of sand-sheets within shallow lakes or alluvial plain settings. We interpret the coarser deposits as formed by sheet-flood sand-bed rivers sensu Miall (1996).

- The second type of depositional environment is represented by thick sequences of Sh facies (at Chahe, Bed 32-34, Fig. 2, and Zhejue, Bed 42-46, Fig. 3) or St facies (at Jiucaichong, Bed 6,7, $8-10$, and 19, Fig. 4), fining upward to Fl facies. The top of the sand bars are generally represented by the Sh facies with some current ripples attesting to decreasing flow rates. These genetic sequences are thicker (5-7 m) compared to those in the lower part of the succession. These are interpreted to represent increased flash discharges (Sh facies at Chahe and Zhejue) within swamps and shallow lake deposits. At Jiucaichong these are instead interpreted to represent low sinuosity braided river deposits (St facies) within shallow lake or alluvial plain deposits. Increasing lacustrine influence is further indicated by the occurrence of freshwater algal cysts in palynological samples within the upper part of the Xuanwei Formation. The transition from the more terrestrially influenced lower part and the more lacustrine/riparian-influenced upper part is marked by a drop in plant diversity around Bed 29 at Chahe, associated with the onset of a thick sandstone unit representing a flash discharge event (Beds 32-34).

The Gigantopteris flora recovered from the Xuanwei Formation at all four sections is indicative of a warm and humid climate. The taxa present are typical climate-sensitive, hygrophilous wetland plants (DiMichele and Philips, 2002; DiMichele et al., 2005a, 2006a). This interpretation is further supported by the occurrence of organic-rich horizons throughout the Xuanwei Formation. Additionally, the palynological assemblages from the four studied sections show relative abundance of nearly $100 \%$ spores. Conifer pollen (monosaccate and taeniate bisaccate pollen grains) are absent from the palynological assemblages, with the vast dominance of spores indicating hygrophilous affinity. Interestingly, an important proportion of fossil plants recorded in the Xuanwei Formation are pollen producers (Cordaitales, pteridosperms and ginkgoales). There is therefore a mismatch between the composition of macroflora and palynological assemblages, which could be related to preservational or taphonomic bias.

Occurrence of Stigmaria was reported in several plant-producing units (Table 2). Stigmaria is a form-genus for the rootlet-bearing rhizome of the lycopsid Lepidodendron. The rhizophores develop horizontally and shallow within the soil horizon, and usually get preserved as in-situ three-dimensional casts in Pennsylvanian and Early Permian coal swamp environments (Martín-Closas and Galtier, 2005; Wagner and Diez, 2007). In the Xuanwei Formation, Stigmaria are preserved as organic compressions without any connected rootlets, within laminated silty sandstone (Sh facies), often associated with plant debris. This contrasts with the usual ecological interpretation of Stigmaria representative of gleyed paleosols (Rosenau et al., 2013). Gleyed soil activity is characterized by structureless claystones units with slickensides, obliterating sedimentary features as well as potential fossil plant compressions. We therefore propose that Stigmaria rhizophores were transported together with the subaerial plant remains, rather than being preserved in-situ, although this scenario would not be usual in a typical Pennsylvanian coal swamp environment (Ferguson, 1970).

\subsection{Kayitou Formation}

The monotonous succession of massive silty mudstone facies (Fm facies) with intercalation of very fine planar lamination (Fl facies) indicates deposition in calm, ever-flooded aqueous environments. Deposition of the Kayitou Formation corresponds to a shallow coastal terrestrial lagoon evolving towards marine deposition at the Mide section. The general facies progradation observed at all sections may be associated with a regional marine transgression recorded at the beginning of the Triassic (Lehrmann et al., 2007; Yin et al., 2014).

At the Mide section, the occurrence of marine bivalves, brachiopods, ammonoids and ostracods (Yu et al., 2010) clearly indicates a marine depositional setting. We found several 3-5 mm spinicaudatan valves at Jiucaichong, possibly indicating freshwater environments (Kozur and Weems, 2010), albeit precise taxonomical identification of the specimens was not yet established. These interpretations are strengthened by the presence of typical marine Hollinellid ostracods. The monogeneric assemblage further indicate unstable conditions that can relate to the modification of one or more paleoecological parameters, such as temperature, salinity, oxygenation and amount of suspended matter. Hollinella 
is an important environmental proxy since its size has been correlated with proximity to the paleoshoreline and detrital input: small species tend to be relatively offshore inhabitants whereas larger ones occur closer to shore and can handle strong terrestrial influx (Melnyk and Maddocks, 1988). All the specimens found here are large (around $1 \mathrm{~mm}$ long), denoting conditions close to the shoreline under relatively strong detrital input.

The warm and humid climate evidenced from the Xuanwei Formation also prevail across the PTB and in the lowermost Kayitou Formation. The Annalepis-Peltaspermum assemblage is mainly composed of hygrophilous, climate-sensitive plants (MartínClosas, 2003). Much like the Gigantopteris flora of the Xuanwei Formation, the lycopsids and pteridosperms of the lowermost Kayitou Formation indicates a warm and humid climate.

\subsection{Dongchuan Formation}

The Dongchuan Formation is composed of redbeds, occurring in stacked fining-upward sequences of Sh and St facies with each stack comprising $0.5-2 \mathrm{~m}$. The increasing occurrence of the St facies with stacked trough cross-bedding, characteristic of braided rivers (Best and Bristow, 1993; Miall, 1996) indicates a progressive change in depositional environment to braided rivers within semiarid alluvial floodplains.

Evidence of pedogenesis is not found across the Dongchuan Formation and organic matter is absent. The Dongchuan Formation represents the first evidence of redbeds in South China with depositional environment similar to what is known from the Late Permian of North China (Shu and Norris, 1999; Yang et al., 2010; Thomas et al., 2011; Stevens et al., 2011), South Africa (Ward et al., 2000; Gastaldo et al., 2005; Coney et al., 2007), Russia (Benton et al., 2004), Europe (Körner et al., 2003; Schneider et al., 2006; Bourquin et al., 2006, 2007; Bercovici et al., 2009b), and the Early to Middle Permian of North America (DiMichele et al., 2004, 2005b, 2007), with climate change to drier conditions (Sheldon, 2005). During the end of the Paleozoic, plants had been tracking the effects of global climate change (Rees et al., 2002), and South China represents the ultimate place where wetland floras still thrived close to the PTB (DiMichele et al., 2001, 2006b; Hilton and Cleal, 2007). This climate change to drier conditions is gradual, with onset marked by the occurrence of variegated deposits in the top of the Kayitou Formation.

\section{Placement of the PTB}

\subsection{Radiometric ages}

Traditionally, correlation of the PTB successions across the Yangtze platform has been performed using the PTBST as a marker (Peng and Shi, 2009), based on an array of stratigraphic methods not necessarily including biostratigraphy (Peng et al., 2001; Peng et al., 2002; Wang and Yin, 2001; Peng et al., 2005; Peng et al., 2006; Yu et al., 2007). The PTBST "eventostratigraphic clay" correspond to Bed 68 at Chahe, Bed 21 at Jiucaichong and Bed 49 Zhejue (Figs. 2-4 and 12) whereas Mide does not host any noticeable clay bed (Fig. 5). This so called "eventostratigraphic clay" has been identified as a bentonite in Bed 68 at Chahe (Shen et al., 2011a). Lithostratigraphic correlations are demonstrably insufficient on their own, but recent high-resolution radiometric dating (Shen et al., 2011a) has greatly supported the correlation of the PTBST between Meishan and Chahe (Fig. 12). Bed 25 at Meishan was dated at $252.28 \pm 0.08 \mathrm{Ma}$, very close to the age of $252.30 \pm 0.07 \mathrm{Ma}$ recorded for of Bed 68 at Chahe (Shen et al., 2011a). Our results on the new Jiucaichong exposure shows that this bentonite bed is also present at the top of the Xuanwei Formation (Bed 21a,
Fig. 6F). Based on the stratigraphic position of this bentonite bed and the geographic proximity of the Chahe, Zhejue and Jiucaichong sections (Fig. 1), Bed 68 at Chahe, Bed 21 at Jiucaichong and Bed 49 at Zhejue can tentatively be correlated (Fig. 12). This working hypothesis needs to be confirmed by performing high-resolution radiometric dating of Jiucaichong Bed 21 and Zhejue Bed 49.

\subsection{Paleobotany}

The Annalepis-Peltaspermum assemblage evidenced in the lowermost part of the Kayitou Formation contrasts significantly with the composition of the Gigantopteris flora recovered from the underlying Xuanwei Formation. The presence of Annalepis from the Mide and Tucheng sections (Yu et al., 2010), represents the first occurrence of a typical Triassic element. Annalepis is common in the Middle Triassic of Europe and South China, but at Mide and Tusheng this flora is encountered in the lowermost part of the Kayitou Formation, consequently assigned to the lowermost Triassic (Yu et al., 2010). Peltasperms are common elements of the latePaleozoic floras, and are mostly represented in our assemblages from South China by the gigantopterids in the Xuanwei Formation. They are also known from the Triassic (Retallack, 2002; Wachtler, 2011), and we reported the occurrence of Peltaspermum sp. (Fig. 7I) and Lepidopteris cf. martinsii (Fig. 7G) in the basal Kayitou Formation. In South China, Annalepis and Peltaspermum represents the pioneer species in the restructuring of the Early Triassic plant ecosystems.

Interestingly, fragments of gigantopterids were also encountered within the Annalepis-Peltaspermum macrofloral assemblage at the Tusheng section (Yu et al., 2010). Three specimens are shown in Yu (2008), representing two $<1 \mathrm{~cm}$ fragments of Gigantopteris sp. and one of Gigantonoclea sp. Two interpretations for the presence of these persisting relicts of the Late Permian Gigantopteris flora in the early Triassic are possible: either as survivor of the EPE, or as reworked elements. Short-term survivorship of the Gigantopteris flora is a likely possibility, because plant compressions are not prone to reworking. Gigantopterids clearly lost dominance as they are represented in very low numbers within the Annalepis-Peltaspermum assemblage of the Tusheng section. Similar short-term survival of organism was evidenced at the PTB in the marine realm (Payne et al., 2013), and also in the earliest Paleogene, immediately after the end-Cretaceous mass extinction event (Bercovici et al., 2009c, 2012b; Landman et al., 2012). Pteridosperms were also components of Mesozoic ecosystems, and persisted till the beginning of the Cenozoic (McLoughlin et al., 2008). However, considering the fragmentary nature of the plant debris recovered from the Kayitou Formation and the transport involved for depositing terrestrial plant debris in near-shore marine environments, the Annalepis-Peltaspermum assemblage might also constitute an allochthonous assemblage of transported elements.

\subsection{Palynostratigraphy}

The relative abundance of spores and pollen recorded here differs greatly from those presented by Peng et al. (2006), who recorded significant quantities of pollen within the Xuanwei Formation (18.3\% at Chahe and $17.5 \%$ at Zhejue). Peng et al. (2006) noted a relative increase of pollen grains towards the top of the Xuanwei Formation, especially above the PTBST where the assemblages were described as dominated by pollen grains $(66.6 \%$ at Chahe and 59.6\% at Zhejue). More recently, Shen et al. (2011a) also provided a figure of $5 \%$ gymnosperm in samples stratigraphically below the end-Permian carbon isotope negative shift at Longmendong, Chuanyang and Chahe sections and those results are more compatible with our observations. Unfortunately, the low numbers 
of pollen and spores recovered from the sediments of the four studied sections makes them unsuitable markers of the PTB and EPE.

\subsection{The PTB "fungal spike" event}

An "anomalously high abundance" of fungal spores at the top of the Xuanwei Formation was noted by Peng and Shi (2009) in agreement with our results of relative fungal abundance close to $100 \%$ in some samples (Supplement Table 1). At least seven taxa of fungal spores were identified in our palynological samples, among which Reduviasporonites characterizes the end-Permian fungal spike worldwide (Visscher et al., 1996). Recent debate has questioned the significance of this fungal event, and more specifically the affinity of these organic-walled microfossils due to their close morphological resemblance to the zygnematalean green algae Tympanicysta (Afonin et al., 2001; Foster et al., 2002). However, Visscher et al. (2011) argued that Tympanicysta occurs mostly in very recent sediments because of the low preservational potential of this fragile and thin-walled algal cyst. Moreover, organic geochemical analysis of Reduviasporonites that exclude the sedimentary matrix shows a signature not related to algal cysts but rather to fungal spores (Sephton et al., 2008; Visscher et al., 2011). The occurrence of Reduviasporonites immediately before the end-Permian mass extinction would still indicate the onset of terrestrial environmental collapse and organic matter decomposition. Similarly, a fungal spike was also evidenced in association to the devastation of terrestrial plant ecosystems at the Cretaceous-Paleogene boundary (Vajda and McLoughlin, 2004, 2007; Vajda and Bercovici, 2014). In all four studied sections, fungal spores and Reduviasporonites only occur within a restricted stratigraphic interval at the very top of the Xuanwei Formation, corresponding to latest Permian deposits.

\subsection{Invertebrate biostratigraphy}

Evidence of marine fossils has been reported in the lowermost part of the Kayitou Formation at Mide and Tusheng sections (Yu et al., 2010). Among these fossils, occurrence of the ammonoid Ophiceras sp. in Mide Bed 25 (Fig. 12, Tian et al., 2008; Yu et al., 2010) clearly indicates Early Triassic (Griesbachian) age (Brühwiler et al., 2008). The bivalve assemblage is diverse and includes Unionites fassaensis, U. canalensis, U. sp., Towapteria schythica, T. sp., Leviconcha orbicularis, L. prazorbicularis, Pteria ussurica, $P$. ussurica variabilis, P. murchisoni leshanensis, P. sp., Bakevellia exporrecta linearis, Eumorphotis sp., Neoschizodus laevigata, Promayalina cf. minuta and Gervillia pannonica (Yu et al., 2010). Collectively, this assemblage represents a Lower Triassic range (Rong and Fang, 2004; Posenato et al., 2005). The monogeneric Hollinella ostracod assemblage recovered from the lowermost part of the Kayitou Formation at Mide is however not age diagnostic, as it is typically encountered in the Permian at large and is known to persist shortly during the Early Triassic. The spinicaudatans recovered from Chahe Bed 70 and Jiucaichong Bed 24-26 (Fig. 12) were attributed to the genera Euestheria and Palaeolimnadia by Chu et al. (2013), and could potentially be indicative of Triassic age (Tash and Jones, 1979; Kozur and Weems, 2010; Chu et al., 2013).

\section{Conclusions}

Four exposures spanning the PTB, located in Western Guizhou and Eastern Yunnan, China were studied for sedimentology, paleontology and geochemistry. The studied interval spans parts of the Xuanwei, Kayitou and Dongchuan formations where three major types of depositional environments were identified based mainly on the sedimentological results. The vertical successions show an evolution from alluvial and lacustrine deposits with few channel deposits (sheet-flood sand-bed and braided rivers) to coastal marine deposits, and finally to braided rivers within semi-arid alluvial plains. The sediments exposed at the new Jiucaichong section have a stronger fluvial influence in the upper part of the Xuanwei Formation compared to the two adjacent Chahe and Zhejue sections (which are more lake-influenced), revealing a transition from proximal (onshore sediments) at Jiucaichong, to distal (paralic/marine) successions at the Mide section.

There is still an ongoing discussion regarding the ages of these successions. Shen et al. (2011a) placed the PTB at the Chahe section within the Dongchuan Formation, $\sim 14 \mathrm{~m}$ above the bentonite Bed 68 . The position was based on three criteria including a negative carbon isotope anomaly, the presence of charcoal interpreted to signify wildfires associated with the PTB, and a color change of the sediments to red/purple (Shen et al., 2011a,b). We argue that the PTB should be in proximity to the bentonite bed at Chahe, dated at $252.30 \pm 0.07 \mathrm{Ma}$ (Shen et al., 2011a), which closely coeval to the PTB at the Meishan GSSP. The FADs of typical Triassic (Induan) bivalves, spinicaudatans, and ammonites reported from the basal part of the Kayitou Formation, associated with the Triassic plant genus Annalepis in the coastal Mide and Tusheng sections (Yu et al., 2010), support this interpretation. Moreover, we identified a single zone enriched in fungal spores including Reduviasporonites, close to the formation contact between the Xuanwei and Kayitou formations at all four sections, including Chahe close to Bed 68 (Fig. 12).

The disappearance of plants and palynomorphs in the basal Kayitou Formation from these successions has previously been attributed to the EPE. However, we show a major regional facies change occur between the Xuanwei and Kayitou formations that likely account for preservational differences. It is however clear that two distinct plant assemblages occur across the formation contact between the Xuanwei and Kayitou formations in Western Guizhou and Eastern Yunnan: The Gigantopteris flora of the Upper Xuanwei Formation, and the Annalepis-Peltaspermum assemblage in the basal part of the Kayitou Formation (Fig. 12). The Gigantopteris flora (Gigantonoclea guizhouensis-Annularia pingloensis assemblage) has previously been attributed to the Late Permian (Changhsingian) whilst the Annalepis-Peltaspermum assemblage has been attributed to the Early Triassic (Induan; Yu et al., 2010). Similar floral turnover associated to the EPE has been evidenced globally (Wang, 1996; Looy et al., 1999, 2001; Rees, 2002; Lindström and McLoughlin, 2007; Krassilov and Karasev, 2009; Hochuli et al., 2010; McLoughlin, 2011), with lycopsids involved in the recovery phase during the Early Triassic (Retallack, 1997; Wang and Chen, 2001; Grauvogel-Stamm and Lugardon, 2001; Naugolnykh, 2013). Importantly, the typical Permian gigantopterids persist as relicts within the Triassic Annalepis-Peltaspermum Assemblage. It could imply that gigantopterids cannot be used as a reliable Permian marker in South China if their occurrence represent short-term survival.

\section{Acknowledgements}

This work was supported by the NSFC (project no. 40972002 and 41272024) and by the State Key Laboratory of Biogeology and Environmental Geology, China University of Geosciences, Wuhan (program GBL11302). A. Bercovici is supported through the Swedish Research Council (VR) postdoctoral fellowship grant 2011-7176. Ying Cui acknowledges support from NSF grant EAR0807744. We are thankful to Wei Zhang and students from China University of Geosciences (Wuhan) for assistance in the field. This work was further supported by Lund University Carbon Cycle Center LUCCI, through the Swedish Research Council. We are grateful to Serge V. Naugolnykh and an anonymous reviewer for providing fast and constructive comments that helped improve the manu- 
script, and to Steve McLoughlin for discussions and careful review of the english style.

\section{Appendix A. Supplementary material}

Supplementary data associated with this article can be found, in the online version, at http://dx.doi.org/10.1016/j.jseaes.2014.11. 016. These data include Google maps of the most important areas described in this article.

\section{References}

Afonin, S.A., Barinova, S.S., Krassilov, V.A., 2001. A bloom of Tympanicysta Balme (green algae of zygnematalean affinities) at the Permian-Triassic boundary. Geodiversitas 23, 481-487.

Balme, B.E., 1970. Palynology of Permian and Triassic strata in the Salt Range and Surghar Range, West Pakistan. In: Kummel, B., Teichert, C. (Eds.), Stratigraphic Boundary Problems: Permian and Triassic of West Pakistan. University Press of Kansas, Department of Geology Special Publication 4, pp. 305-453.

Benton, M.J., Newell, A.J., 2014. Impacts of global warming on Permo-Triassic terrestrial ecosystems. Gondwana Res. 25, 1308-1337.

Benton, M.J., Tverdokhlebov, V.P., Surkov, M.V., 2004. Ecosystem remodeling among vertebrates at the Permian-Triassic boundary in Russia. Nature 432, 97-100.

Bercovici, A., Hadley, A., Villanueva-Amadoz, U., 2009a. Improving depth of field resolution for palynological microphotography. Palaeontol. Electron. 12, 1-12.

Bercovici, A., Diez, J.B., Broutin, J., Bourquin, S., Linol, B., Villanueva-Amadoz, U., López-Gómez, J., Durand, M., 2009b. A palaeoenvironmental analysis of Permian sediments in Minorca (Balearic Islands, Spain) with new palynological and mega floral data. Rev. Palaeobot. Palynol. 158, 14-28.

Bercovici, A., Pearson, D.A., Nichols, D.J., Wood, J., 2009c. Biostratigraphy of selected K/T boundary sections in southwestern North Dakota, USA: toward a refinement of palynological identification criteria. Cretac. Res. 30, 632-658.

Bercovici, A., Bourquin, S., Broutin, J., Steyer, J.-S., Battail, B., Véran, M., Vacant, R. Khenthavong, B., Vongphamany, S., 2012a. Permian continental paleoenvironments in southeastern Asia: new insights from the Luang Prabang Basin (Laos). J. Asian Earth Sci. 60, 197-212.

Bercovici, A., Pearson, D.A., Vajda, V., Villanueva-Amadoz, U., Kline, D., 2012b. Palynostratigraphy of John's Nose, a new Cretaceous-Paleogene boundary section in southwestern North Dakota, USA. Palynology 36, 36-47.

Berthelin, M., Vozenin-Serra, C., Broutin, J., 2004. Phytogeographic and climatic implications of Permian woods discoveries in Oman. Palaeontogr. Abt. B 268, 93-112.

Best, J.L., Bristow, C.S., 1993. Braided rivers. Geological Society of London Special Publication 75, pp. 1-11.

Blanchard, S., Rossignol, C., Bourquin, S., Dabard, M.-P., Hallot, E., Nalpas, T., Poujol, M., Battail, B., Jalil, N., Steyer, J.-S., Vacant, R., Véran, M., Bercovici, A., Diez, J.B., Paquette, J.-L., Khenthavong, B., Vongphamany, S., 2013. An integrated structural, stratigraphical, paleontological and geochronological study of the Luang Prabang Basin (Laos): an insight into the Permian and Triassic. J. Asian Earth Sci. 70-71, 8-26.

Bourquin, S., Péron, S., Durand, M., 2006. Lower Triassic sequence stratigraphy of the western part of the Germanic Basin (west of Black Forest): fluvial system evolution through time and space. Sed. Geol. 186, 187-211.

Bourquin, S., Durand, M., Diez, J.B., Broutin, J., Fluteau, F., 2007. The PermianTriassic boundary and Lower Triassic sedimentation in the western European basins. J. Iberian Geol. 33, 221-236.

Bourquin, S., Bercovici, A., López-Gómez, J., Diez, J.B., Broutin, J., Arche, A., Linol, B., Amour, F., 2011. The Permian-Triassic boundary and the beginning of the Mesozoic sedimentation at the northwestern peri-Tethyan domain scale: paleogeographic maps and geodynamic implications. Palaeogeogr. Palaeoclimatol. Palaeoecol. 299, 265-280.

Brongniart, A., 1822. Sur la classification et la distribution des végétaux fossiles en général, et sur ceux des terrains de sédiment supérieur en particulier. Mémoires Du Muséum d'Histoire Naturelle 8, 203-240.

Brühwiler, T., Brayard, B., Bucher, B., Guodun, K., 2008. Griesbachian and Dienerian (Early Triassic) ammonoid faunas from Northwestern Guangxi and Southwestern Guizhou (South China). Palaeontology 51, 1151-1180.

Burgess, S.D., Bowring, S., Shen, Shu-Zhong, 2014. High-precision timeline for Earth's most severe extinction. Proc. Natl. Acad. Sci.. http://dx.doi.org/10.1073/ pnas.1317692111.

Chen, Zhong-Qiang, Benton, M.J., 2012. The timing and pattern of biotic recovery following the end-Permian mass extinction. Nat. Geosci. 5, 375-383.

Chen, Zhong-Qiang, Algeo, T.J., Bottjer, D.J., 2014a. Global review on the Permian-Triassic mass extinction and subsequent recovery: Part I. Earth-Sci. Rev. 137, 1-5.

Chen, Zhong-Qiang, Yang, Hao, Luo, Mao, Benton, M.J., Kaiho, Kunio, Zhao, Laishi, Huang, Yuangeng, Zhang, Kexing, Fang, Yuheng, Jiang, Haishui, Qiu, Huan, Li, Yang, Tu, Chengyi, Shi, Lei, Zhang, Lei, Feng, Xueqian, Chen, Long, 2014b. Complete biotic and sedimentary records of the Permian-Triassic transition from Meishan section, South China: Ecologically assessing mass extinction and its aftermath. Earth-Sci. Rev.. http://dx.doi.org/10.1016/j.earscirev.2014.10.005.
Chu, Dao-Liang, Tong, Jin-Nan, Yu, Jian-Xin, Song, Hai-Jun, Tian, Li, 2013. The conchostracan fauna from the Kayitou Formation of western Guizhou, China. Acta Palaeontol. Sin. 52, 265-276.

Colwell, R.K., Mao, Chang-Xuan, Chang, Jing, 2004. Interpolating, extrapolating, and comparing incidence-based species accumulation curves. Ecology 85, 2717-2727.

Coney, L., Reimold, U., Hancox, P., Mader, D., Koeberl, C., McDonald, I., Struck, U., Vajda, V., Kamo, S., 2007. Geochemical and mineralogical investigation of the Permian-Triassic Boundary in the Continental Realm of the Southern Karoo Basin, South Africa. Palaeoworld 16, 67-104.

Crasquin, S., Forel, M.-B., 2014. Ostracods (Crustacea) though Permian-Triassic events. Earth-Sci. Rev. 137, 52-64.

Crasquin, S., Forel, M.-B., Feng, Qing-Lai, Yuan, Ai-Hua, Baudin, F., Collin, P.-Y., 2010 Ostracods (Crustacea) through the Permian-Triassic boundary in South China: the Meishan stratotype (Zhejiang Province). J. Syst. Paleontol. 8, 331-370.

Crasquin-Soleau, S., Marcoux, J., Angiolini, L., Nicora, A., 2004. Palaeocopida (Ostracoda) across the Permian-Triassic events: new data from the SouthWestern Taurus (Turkey). J. Micropalaeontol. 23, 67-76.

Cui, Ying, Kump, L.R., 2014. Global warming and the end-Permian extinction event: proxy and modeling perspectives. Earth Sci. Rev. http://dx.doi.org/10.1016/ j.earscirev.2014.04.007.

Cui, Ying, Kump, L.R., Ridgwell, A., 2013. Initial assessment on the carbon emission rate and climatic consequences during the end-Permian mass extinction. Palaeogeogr. Palaeoclimatol. Palaeoecol. 387, 176-184.

De Jersey, N.J., 1962. Triassic spores and pollen grains from the Ipswich Coalfield Geol. Surv. Queensland Publ. 307, 1-18.

DiMichele, W.A., Philips, T.L., 2002. The ecology of Paleozoic ferns. Rev. Palaeobot. Palynol. 119, 143-159.

DiMichele, W.A., Pfefferkorn, H.W., Gastaldo, R.A., 2001. Response of Late Carboniferous and Early Permian plant communities to climate change. Annu. Rev. Earth Planet. Sci. 29, 461-487.

DiMichele, W.A., Hook, R.W., Nelson, J.W., Chaney, D.S., 2004. An unusual Middle Permian flora from the Blaine Formation (Pease River Group: LeonardianGuadalupian series) if King County, West Texas. J. Paleontol. 78, 765-782.

DiMichele, W.A., Kerp, H., Krings, M., Chaney, D.S., 2005a. The Permian Peltasperm Radiation: Evidence from the Southwestern United States. In: Lucas, S.G. Zeigler, K.E., (Eds.), The Nonmarine Permian, New Mexico Museum of Natural History and Science Bulletin, vol. 30, pp. 67-79.

DiMichele, W.A., Tabor, N.J., Chaney, D.S., 2005b. Outcrop-scale Environmental Heterogeneity and Vegetational Complexity in the Permo-Carboniferous Markley Formation of North Central Texas. In: Lucas, S.G., Zeigler, K.E., (Eds.), The Nonmarine Permian, New Mexico Museum of Natural History and Science Bulletin, vol. 30, pp. 60-66.

DiMichele, W.A., Philips, T.L., Pfefferkorn, H.W., 2006a. Paleoecology of Late Paleozoic pteridosperms from tropical Euramerica. J. Torrey Bot. Soc. 133, 83-118.

DiMichele, W.A., Taboe, N.J., Chaney, D.S., Nelson, W.J., 2006b. From Wetlands to Wet Spots: Environmental Tracking and the Fate of Carboniferous Elements in Early Permian Tropical Floras. In: Greb, S.F., DiMichele, W.A., (Eds.), Wetlands Through Time: Geological Society of America Special Paper, vol. 399, pp. 223-248.

DiMichele, W.A., Chaney, D.S., Nelson, W.J., Lucas, S.G., Looy, C.V., Quick, K., Jun, W. 2007. A low diversity, seasonal tropical landscape dominated by conifers and peltasperms: Early Permian Abo Formation, New Mexico. Rev. Palaeobot. Palynol. 145, 249-273.

Einsele, G., 2000. Sedimentary Basins: Evolution, Facies and Sediment Budget. Springer, p. 792.

Erwin, D.H., 2006. Extinction: How Life on Earth Nearly Ended 250 million years ago. Princeton University Press, Princeton, 296p.

Eshet, Y., Rampino, M.R., Visscher, H., 1995. Fungal event and palynological record of ecological crisis and recovery across the Permian-Triassic boundary. Geology 23, 967-980.

Feng, Qing-Lai, Algeo, T.J., 2014. Evolution of oceanic redox conditions during the Permo-Triassic transition: evidence from deepwater radiolarian facies. EarthSci. Rev. 137, 34-51.

Ferguson, L., 1970. Sedimentary evidence for the allochthonous origin of Stigmaria Carboniferous, Nova Scotia: discussion. Geol. Soc. Am. Bull. 81, 2531-2534.

Forel, M.-B., Crasquin, S., 2011. Lower Triassic ostracods (Crustacea) from the Meishan section, Permian-Triassic boundary GSSP (Zhejiang Province, South China). J. Syst. Paleontol. 9, 455-466.

Foster, C.B., Stephenson, M.H., Marshall, C., Logan, G.A., Greenwood, P.F., 2002. A revision of Reduviasporonites Wilson 1962: Description, illustration, comparison and biological affinities. Palynology 26, 35-58.

Gastaldo, R.A., Adendorff, R., Bamford, M., Labandeira, C.C., Neveling, J., Sims, H., 2005. Taphonomic trends of macrofloral assemblages across the PermianTriassic boundary, Karoo Basin. Palaios 20, 479-497.

Ghibaudo, G., 1992. Subaqueous sediment gravity flow deposits: practical criteria for their description and classification. Sedimentology 39, 423-454.

Gotelli, N.J., Colwell, R.K., 2001. Quantifying biodiversity: procedures and pitfalls in the measurement and comparison of species richness. Ecol. Lett. 4, 379-391.

Grauvogel-Stamm, L., Duringer, P., 1983. Annalepis zeilleri Fliche 1910 emend., un organe reproducteur de Lycophyte de la Lettenkohle de l'Est de la France. Morphologie, spores in situ et paléoécologie. Geol. Rundsch. 72, 23-51.

Grauvogel-Stamm, L., Lugardon, B., 2001. The Triassic Lycopsid Pleuromeia and Annalepis: relationship, evolution, and origin. Am. Fern J. 91, 115-149.

Gu, Zhi, 1974. An Introduction to Chinese Fossils, Chinese Plant Fossils: 1. Chinese Palaeozoic Plants. Scientific Publishing House, Beijing, pp. 1-227. 
Halle, T.G., 1927. Palaeozoic plants from central Shansi. Palaeontol. Sin. A2, 1-316. Halle, T.G., 1928. On leaf-mosaic and anisophylly in Palaeozoic equisetales. Svensk Botanisk Tidskrift 22, 230-255.

Harris, T.M., 1932. The fossil flora of Scoresby Sound East Greenland. Meddelelser om Grønland 85, 3-109.

He, Bin, Xu, Yi-Gang, Huang, Xiao-Long, Luo, Zhen-Yu, Shi, Yu-Ruo, Yang, Qi.-Jun., Yu, Song-Yue, 2007. Age and duration of the Emeishan flood volcanism, SW China: Geochemistry and SHRIMP zircon U-Pb dating of silicic ignimbrites, post-volcanic Xuanwei Formation and clay tuff at the Chaotian section. Earth Planet. Sci. Lett. 225, 306-323.

Hilton, J., Cleal, C.J., 2007. The relationship between Euramerican and Cathaysian tropical floras in the Late Palaeozoic: palaeobiogeographical and palaeogeographical implications. Earth-Sci. Rev. 85, 85-116.

Hochuli, P.A., Hermann, E., Vigran, J.O., Bucher, H., Weissert, H., 2010. Rapid demise and recovery of plant ecosystems across the end-Permian extinction event. Global Planet. Change 74, 144-155.

Ibrahim, A., 1932. Beschreibung von Sporenformen aus Flöz Ägir. In: Potonié, R., (Ed.), Sporomorphen aus der Flözen Ägir und Bismarck des Ruhrgebietes. Neues Jhrbuch für Mineralogie, Geologie und Paläontologie Beilage-Band. Abteilung B, Geologie une Paläontologie, vol. 67, pp. 447-449.

Körner, F., Schneider, J.W., Hoernes, S., Gand, G., Kleeberg, R., 2003. Climate and continental sedimentation in the Permian of the Lodève basin (Southern France). Bull. Soc. Géol. France Spécial 2, 185-192.

Kosanke, R.M., 1950. Pennsylvanian spores of Illinois and their use in correlation. Illinois Geol. Surv. Bull. 74, 1-128.

Kozur, H.W., Weems, R.E., 2010. The biostratigraphic importance of conchostracans in the continental Triassic of the northern hemisphere. Geological Society of London Special Publications 334, pp. 315-417. doi: http://dx.doi.org/10.1144/ SP334.13.

Krassilov, V., Karasev, E., 2009. Paleofloristic evidence of climate change near and beyond the Permian-Triassic boundary. Palaeogeogr. Palaeoclimatol. Palaeoecol. 284, 326-336.

Landman, N.H., Garb, M.P., Rovelli, R., Ebel, D.S., Edwards, L.E. 2012. Short-term survival of ammonites in New Jersey after the end-Cretaceous bolide impact Acta Paleontol. Polon. 57, 703-715.

Lehrmann, D.J., Payne, J.L., Pei, Dong-Hong, Enos, P., Druke, D., Steffen, K., Zhang, JiNan, Wei, Jia-Yong, Orchad, M.J., Ellwood, B., 2007. Record of the end-Permian extinction and Triassic biotic recovery in the Chongzuo-Pingguo platform, southern Nanpanjiang basin, Guangxi, south China. Palaeogeogr. Palaeoclimatol. Palaeoecol. 252, 200-217.

Lindström, S., McLoughlin, S., 2007. Synchronous palynofloristic extinction and recovery after the end-Permian event in the Prince Charles Mountains, Antarctica: implications for palynofloristic turnover across Gondwana. Rev. Palaeobot. Palynol. 145, 89-122.

Looy, C.V., Brugman, W.A., Dilcher, D.L., Visscher, H., 1999. The delayed resurgence of equatorial forests after the Permian-Triassic ecologic crisis. Proc. Natl. Acad. Sci. 96, 13857-13862.

Looy, C.V., Twitchett, R.J., Dilcher, D.L., Van Konijnenburg-van Cittert, J.H.A., Visscher, H., 2001. Life in the end-Permian dead zone. Proc. Natl. Acad. Sci. 98, 7879-7883.

Lowe, D.R., 1982. Sediment gravity flows: II. Depositional models with special reference to the deposits of high-density turbidity currents. J. Sediment. Petrol. 52, 279-297.

Lucas, S.G., Schneider, J.W., Cassinis, G., 2006. Non-marine Permian Biostratigraphy and Biochronology: An Introduction. In: Lucas, S.G., Cassinis, G., Schneider, J.W. (Eds.), Non-marine Permian Biostratigraphy and Biochronology. Geological Society of London Special Publication 265, pp. 1-14.

Martín-Closas, C., 2003. The fossil record and evolution of freshwater plants: review. Geol. Acta 1, 315-338.

Martín-Closas, C., Galtier, J., 2005. Plant taphonomy and Paleoecology of Late Pennsylvanian intramontane Wetlands in the Graissessac-Lodève Basin (Languedoc, France). Palaios 20, 249-265.

McLoughlin, S., 2011. Glossopteris - insights into the architecture and relationship of an iconic Permian Gondwanan plant. J. Bot. Soc. Bengal 65, 1-14.

McLoughlin, S., Carpenter, R.S., Jordan, G.J., Hill, R.S., 2008. Seed ferns survived the end-Cretaceous mass extinction in Tasmania. Am. J. Bot. 95, 465-471.

Melnyk, D.H., Maddocks, R.F., 1988. Ostracode biostratigraphy of the PermoCarboniferous of central and north-central Texas, Part I: Paleoenvironmenta framework. Micropaleontology 34, 1-20.

Meng, Fan-Song, 1998. Studies on Annalepis from Middle Triassic along the Yangtze River and its bearing on the origin of Isoetes. Acta Bot. Sin. 40, 768-774.

Miall, A.D., 1978. Fluvial sedimentology. Memoir Canadian Soc. Petrol. Geol. 5, 859.

Miall, A.D., 1996. The Geology of Fluvial Deposits. Springer, Berlin, 582p.

Naugolnykh, S.V., 2012. Sporophyll morphology and reconstruction of the heterosporous lycopod Tomiostrobus radiatus Neuburg emend. from the Lower Triassic of Siberia (Russia). The Palaeobotanist 61, 387-405.

Naugolnykh, S.V., 2013. The heterosporous lycopodiophyte Pleuromeia rossica Neuburg, 1960 from the Lower Triassic of the Volga River basin (Russia): organography and reconstruction according to the 'whole plant' concept. Wulfenia 20, 1-16

Nilsson, T., 1958. Uber das Vorkommen eines Mesozoichen Sapropelgesteins. Lunds Universitets Årsskrift 54, 5-112.

Ouyang, Shu, 1982. Upper Permian and Lower Triassic palynomorphs from eastern Yunnan, China. Can. J. Earth Sci. 19, 68-80.

Ouyang, Shu, 1986. Palynology of Upper Permian and Lower Triassic strata of Fuyuan district, Eastern Yunnan. Acta Palaeontol. Sin. 169, 1-122.
Ouyang, Shu, Li, Zai-Ping, 1980. Microflora from the Kayitou Formation of Fuyuan district, eastern Yunnan and its bearing on stratigraphy and palaeobotany. In: Sinica, Academia (Ed.), Nanjing Institute of Geology and Palaeontology, Late Permian coal-bearing strata and palaeontological fauna in western Guizhou and eastern Yunnan. Science Press, Beijing, pp. 123-183.

Payne, J., Clapham, M., 2012. End-Permian mass extinction in the oceans: an ancient analog for the 21st century? Ann. Rev. Earth Planet. Sci. 40, 89-111.

Payne, J., Fraiser, M.I., Marenco, P.J., Shen, Shu-Zhong, 2013. Taxonomic composition and environmental distribution of post-extinction rhynchonelliform brachiopod faunas: constraints on short-term survival and the role of anoxia in the end-Permian mass extinction. Palaeogeogr. Palaeoclimatol. Palaeoecol. 374, 284-292.

Peng, Yuan-Qiao, Shi, G.R., 2009. Life crises on land across the Permian-Triassic boundary in South China. Global Planet. Change 65, 155-165.

Peng, Yuan-Qiao, Jin-Nan, Tong, Shi, G.R., Hansen, H.J., 2001. The Permian-Triassic boundary stratigraphic set: characteristics and correlation. Newsl. Stratigr. 39, 55-71.

Peng, Yuan-Qiao, Wang, S.Y., Wang, Y.F., Yang, F.Q., 2002. A proposed area for study of accessory section and point of terrestrial Permian-Triassic boundary. J China Univ. Geosci. 13, 157-162.

Peng, Yuan-Qiao, Zhang, Su-Xin, Yu, Tian-Xin, Yang, Feng-Qing, Gao, Yong-Qun, Shi, G.R., 2005. High-resolution terrestrial Permian-Triassic eventostratigraphic boundary in western Guizhou and eastern Yunnan, southwestern China. Palaeogeogr. Palaeoclimatol. Palaeoecol. 215, 285-295.

Peng, Yuan-Qiao, Yu, Jian-Xin, Gao, Yong-Qun, Yang, Feng-Qing, 2006. Palynological assemblages of non-marine rocks at the Permian-Triassic boundary, western Guizhou and eastern Yunnan, South China. J. Asian Earth Sci. 28, 291-305.

Playford, G., Dettmann, M.E., 1965. Rhaeto-Liassic plant microfossils from the Leigh Creek Coal Measures, South Australia. Senckenb. Lethaea 46, 127-181.

Poort, R.J., Kerp, J.H.F., 1990. Aspects of Permian palaeobotany and palynology. XI. On the recognition of true peltasperms in the Upper Permian of western and central Europe and a reclassification of species formerly included in Peltaspermum Harris. Rev. Palaeobot. Palynol. 63, 196-225.

Posenato, R., Pelikán, P., Hips, K., 2005. Bivalves and brachiopods near the PermianTriassic boundary from the Bükk Mountains (Bálváni-North section, Northern Hungary). Riv. Ital. Paleontol. Stratigr. 111, 215-232.

Potonié, R., Kremp, G.O.W., 1955. Die Sporae dispersae des Ruhrkarbons, ihre Morphographie und Stratigraphie mit Ausblicken auf Arten anderer Gebiete und Zeitabschnitte. Palaeontogr., Abt. B 98, 1-136.

Rees, M.P., 2002. Land-plant diversity and the end-Permian mass extinction. Geology 30, 827-830.

Rees, P.M., Ziegler, A.M., Gibbs, M.T., Kutzbach, J.E., Behling, P.J., Rowley, D.B., 2002. Permian phytogeographic patterns and climate data/model comparisons. J. Geol. 110, 1-31.

Retallack, G.J., 1997. Earliest Triassic origin of Isoetes and quillwort evolutionary radiation. J. Paleontol. 71, 500-521.

Retallack, G.J., 2002. Lepidopteris callipteroides, an earliest Triassic seed fern of the Sydney Basin, southeastern Australia. Alcheringa 26, 475-500.

Retallack, G.J., 2013. Permian and Triassic greenhouse crises. Gondwana Res. 24, 90-103.

Romano, C., Goudemand, N., Vennemann, T.W., Ware, D., Schneebeli-Hermann, E., Hochuli, P.A., Brühwiler, T., Brinkmann, W., Bucher, H., 2012. Climatic and biotic upheavals following the end-Permian mass extinction. Nat. Geosci. 6, 57-60.

Rong, Jia-Yu, Fang, Z.J., 2004. Mass Extinction and Recovery-evidences from the Palaeozoic and Triassic of South China. Univ. Sci. Technol. China Press, Hefei, pp. 636-645.

Rosenau, N.A., Tabor, N.J., Elrick, S.D., Nelson, W.J., 2013. Polygenic history of paleosols in Middle-Upper Pennsylvanian cyclothems of the Illinois Basin, U.S.A.: Part I. Characterization of paleosol types and interpretation of pedogenic processes. J. Sediment. Res. 83, 606-636.

Sandler, A., Eshet, Y., Schilman, B., 2006. Evidence for a fungal event, methanehydrate release and soil erosion at the Permian-Triassic boundary in southern Israel. Palaeogeogr. Palaeoclimatol. Palaeoecol. 242, 68-89.

Schneider, J.W., Körner, F., Roscher, M., Kroner, U., 2006. Permian climate development in the northern peri-Tethys area - the Lodève basin, French Massif Central, compared in a European and global context. Palaeogeogr. Palaeoclimatol. Palaeoecol. 240, 161-183.

Schopf, J.M., Wilson, L.R., Bentall, R., 1944. An annotated synopsis of Paleozoic fossil spores and the definition of generic groups. Illinois State Geological Survey, Report of Investigations 91, 1-66.

Schulz, E., 1964. Sporen und Pollen aus dem Mittleren Buntsandstein des germanischen Beckens. Monatsberichte der deutschen Akademie der Wissenschaften 6, 597-606.

Sephton, M.A., Visscher, H., Looy, C.V., Verchovsky, A.B., Watsin, J.S., 2008. Chemical constitution of a Permian-Triassic disaster species. Geology 37, 875-878.

Sheldon, N.D., 2005. Do red beds indicate paleoclimatic conditions?: A Permian case study. Palaeogeogr. Palaeoclimatol. Palaeoecol. 228, 305-319.

Shen, Shu-Zhong, Crowley, J.L., Wang, Yue, Bowring, S.A., Erwin, D.H., Sadler, P.M., Cao, Chang-Qun, Rothman, D.H., Henderson, C.M., Ramezani, J., Zhang, Hua, Shen, Yan-An, Wang, Xiang-Dong, Wang, Wei, Mu, Lin, Li, Wen-Zhong, Tang, Yue-Gang, Liu, Xiao-Lei, Liu, Lu-Jun, Zeng, Yong, Jiang, Yao-Fa, Jin, Yu-Gan, 2011a. Calibrating the end-Permian mass extinction. Science 334, 1367-1372.

Shen, Wen-Jie, Sun, Yong-Ge, Lin, Yang-Ting, Liu, De-Han, Chai, Ping-Xia, $2011 \mathrm{~b}$. Evidence for wildfire in the Meishan section and implications for PermianTriassic events. Geochim. Cosmochim. Acta 75, 1992-2006. 
Shu, Ou-Yang, Norris, G., 1999. Earliest Triassic Induan spores and pollen from the Junggar Basin, Xinjiang, Northwestern China. Rev. Palaeobot. Palynol. 106, 1-56.

Song, Hai-Jun, Wignall, P.B., Tong, Jin-Nan, Yin, Hong-Fu, 2013. Two pulses of extinction during the Permian-Triassic crisis. Nat. Geosci. 6, 52-56.

Steiner, M.B., Eshet, Y., Rampino, M.R., Schwindt, D.M., 2003. Fungal abundance spike and the Permian-Triassic boundary in the Karoo Supergroup (South Africa). Palaeogeogr. Palaeoclimatol. Palaeoecol. 194, 405-414.

Sternberg, G.K., 1820. Versuch einer geognostischbotanischen Darstellung der Flora der Vorwelt. 80p.

Stevens, L.G., Hilton, J., Bond, D.P.G., Glasspool, I.J., Jardine, P.E., 2011. Radiation and extinction patterns in Permian floras from North China as indicators for environmental Change. J. Geol. Soc. London 168, 607-619.

Sun, Ya-Dong, Johachimski, M.M., Wignall, P.B., Yan, Chun-Bo, Chen, Ya-Long, Jiang, Hai-Shui, Wang, Li-Na, Lai, Xu-Long, 2012. Lethally hot temperatures during the Early Triassic greenhouse. Science 338, 366-370.

Tash, P., Jones, P.J., 1979. Carboniferous, Permian and triassic conchostracans of Australia - three new studies. Bull. Bureau Mineral Resour., Geol. Geophys. 185, $1-66$.

Thomas, S.G., Tabor, N.J., Yang, Wang, Myers, T.S., Yang, Yi, Wang, Dan, 2011. Palaeosol stratigraphy across the Permian-Triassic boundary, Bogda Mountains, NW China: implications for palaeoenvironmental transition through earth's largest mass extinction. Palaeogeogr. Palaeoclimatol. Palaeoecol. 308, 41-64.

Tian, Yun-Tao, Yu, Jian-Xin, Feng, Qing-Lai, 2008. The Discovery of Ophiceras in the Kayitou Formation in Eastern Yunnan Province and its signification. J. Stratigr. 32, 153-158.

Traverse, A., 2007. Paleopalynology. In: Topics in Geobiology, v. 28, second ed. Springer, Dordrecht, Netherlands, p. 813.

Vajda, V., McLoughlin, S., 2004. Fungal proliferation at the Cretaceous-Tertiary boundary. Science 303, 1489.

Vajda, V., McLoughlin, S., 2007. Extinction and recovery pattern of the vegetation across the Cretaceous-Palaeogene boundary - a tool for unravelling the causes of the end-Permian mass-extinction. Rev. Palaeobot. Palynol. 144, 99-112.

Vajda, V., Bercovici, A., 2014. The global vegetation pattern across the CretaceousPaleogene mass extinction interval; a template for other extinction events. Global Planet. Change 122, 29-49.

Visscher, H., Brinkhuis, H., Dilcher, D.L., Elsik, W.C., Eshet, Y., Looy, C.V., Rampino, M.R., Traverse, A., 1996. The terminal Paleozoic fungal event: evidence of terrestrial ecosystem destabilization and collapse. Proc. Natl. Acad. Sci. 93, 2155-2158.

Visscher, H., Looy, C.V., Collinson, M.E., Brinkhuis, H., Van Konijnenburg-Van Cittert, J.H.A., Küschner, W.M., Sephton, M.A., 2004. Environmental mutagenesis during the end-Permian ecological crisis. Proc. Natl. Acad. Sci. 101, pp. 12952-11256.

Visscher, H., Sephton, M.A., Looy, C.V., 2011. Fungal virulence at the time of the endPermian biosphere crisis? Geology 39, 883-886.

Wachtler, M., 2011. Ferns and seedferns from the Early-Middle Triassic (Anisian) Piz da Peres (Dolomites - Northern Italy). Dolomythos, 57-79.

Wagner, R.H., Diez, J.B., 2007. Verdeña (Spain): life and death of a carboniferous forest community. Comptes Rendus Palévol 6, 495-504.

Wang, Zi-Qiang, 1996. Recovery of vegetation from the terminal Permian mass extinction in North China. Rev. Palaeobot. Palynol. 91, 121-142.

Wang, Shan-Yan, Yin, Hong-Fu, 2001. Study on Terrestrial Permian-Triassic Boundary in Eastern Yunnan and Western Guizhou. Press of China University of Geosciences, Wuhan, 88p.
Wang, Zi-Qiang, Chen, An-Shu, 2001. Traces of arborescent lycopsids and dieback of the forest vegetation in relation to the terminal Permian mass extinction in North China. Rev. Palaeobot. Palynol. 117, 217-243.

Ward, P.D., Montgomery, D.R., Smith, R.M.H., 2000. Altered river morphology in South Africa related to the Permian-Triassic extinction. Science 289, 17401743.

Xie, Shu-Cheng, Pancost, R.D., Yin, Hong-Fu, Wang, Hong-Mei, Evershed, R.P., 2005 Two episodes of microbial change coupled with Permo/Triassic faunal mass extinction. Nature 434, 494-497.

Xie, Shu-Cheng, Pancost, R.D., Huang, Xian-Yu, Jiao, Dan, Lu, Li-Qiang, Huang, JunHua, Yang, Feng-Qing, Evershed, R.P., 2007. Molecular and isotopic evidence for episodic environmental change across the Permo/Triassic boundary at Meishan in South China. Global Planet. Change 55, 56-65.

Xiong, Cong-Hui, Wang, Qi, 2011. Permian-Triassic land-plant diversity in South China: was there a mass extinction at the Permian/Triassic boundary? Paleobiology 37, 157-167.

Yang, Wan, Feng, Qiao, Liu, Yi-Qun, Tabor, N., Miggins, D., Crowley, J., Lin, Jin-Yan, Thomas, S., 2010. Depositional environments and cyclo- and chronostratigraphy of Uppermost Carboniferous-Lower Triassic Fluvial-Lacustrine Deposits, Southern Bogda Mountains, NW China - a Terrestrial Paleoclimatic Record of Mid-Latitude NE Pangea. Global Planet. Change 73, 15-113.

Yin, Hong-Fu, Zhang, Ke-Xin, Tong, Jin-Nan, Yang, Zun-Yi, Wu, Shun-Bao, 2001. The Global Stratotype Section and Point (GSSP) of the Permian-Triassic boundary. Episodes 24, 102-114.

Yin, Hong-Fu, Yang, Feng-Qing, Peng, Yuan-Qiao, Wang, Shang-Yan, Zhang, Su-Xin, 2007. An accurately delineated Permian-Triassic boundary in continental successions. Sci. China Ser. D 50, 1281-1292.

Yin, Hong-Fu, Jiang, Hai-Shui, Xia, Wen-Chen, Feng, Qing-Lai, Zhang, Ning, Shen, Jun, 2014. The end-Permian regression in South China and its implication on mass extinction. Earth-Sci. Rev. 137, 19-33.

Yu, Jian-Xin, 2008. Floras and the evolutionary dynamics across the PermianTriassic boundary nearby the border of Guizhou and Yunnan, south China. Ph.D. Thesis, China University of Geosciences, Wuhan, Université Pierre et Marie Curie, Paris 6, 254p.

Yu, Jian-Xin, Peng, Yuan-Qiao, Zhang, Su-Xin, Yang, Feng-Qing, Zhao, Quan-Ming, Huang, Qi-Sheng, 2007. Terrestrial events across the Permian-Triassic boundary along the Yunnan-Guizhou border, SW China. Global Planet. Change 55, 193-208.

Yu, Jian-Xin, Li, Hui-Min, Zhang, Su-Xin, Feng, Qing-Lai, 2008. Timing of the terrestrial Permian-Triassic boundary biotic crisis: implications from $\mathrm{U}-\mathrm{Pb}$ dating of authigenic zircons. Sci. China Ser. D 51, 1633-1645.

Yu, Jian-Xin, Broutin, J., Huang, Qi-Sheng, Grauvogel-Stamm, L., 2010. Annalepis, a pioneering lycopsid genus in the recovery of the Triassic land flora in South China. Comptes Rendus Palévol 9, 479-486.

Zhang, Su-Xin, Peng, Yuan-Qiao, Yu, Jian-Xin, Lei, Xin-Rong, Gao, Yong-Qun, 2006 Characteristics of claystones across the terrestrial Permian-Triassic boundary: evidence from the Chahe section, western Guizhou, South China. J. Asian Earth Sci. 27, 358-370.

Zhao, Quan-Ming, 2003. Study on Depositional Environment and Sequence Stratigraphy of the Terrestrial Permian-Triassic Boundary in Western Guizhou and Eastern Yunnan. Ph.D. Thesis, China University of Geosciences, Wuhan, $133 \mathrm{p}$. 
Appendix Table 1: Palynological preparation report and raw palynofacies count data. Samples showing no organic matter recovery were discarded.

Appendix Table 2: Raw XRF data showing the elemental composition of each sample in ppm. For each samples, four separate analysis were performed and averaged (lines with orange background), with anomalous readings removed from analysis. Calibration of the device was checked regularly using a standard sample of known composition. The calibration results and associated offset is reported at the end of the spreadsheet. 


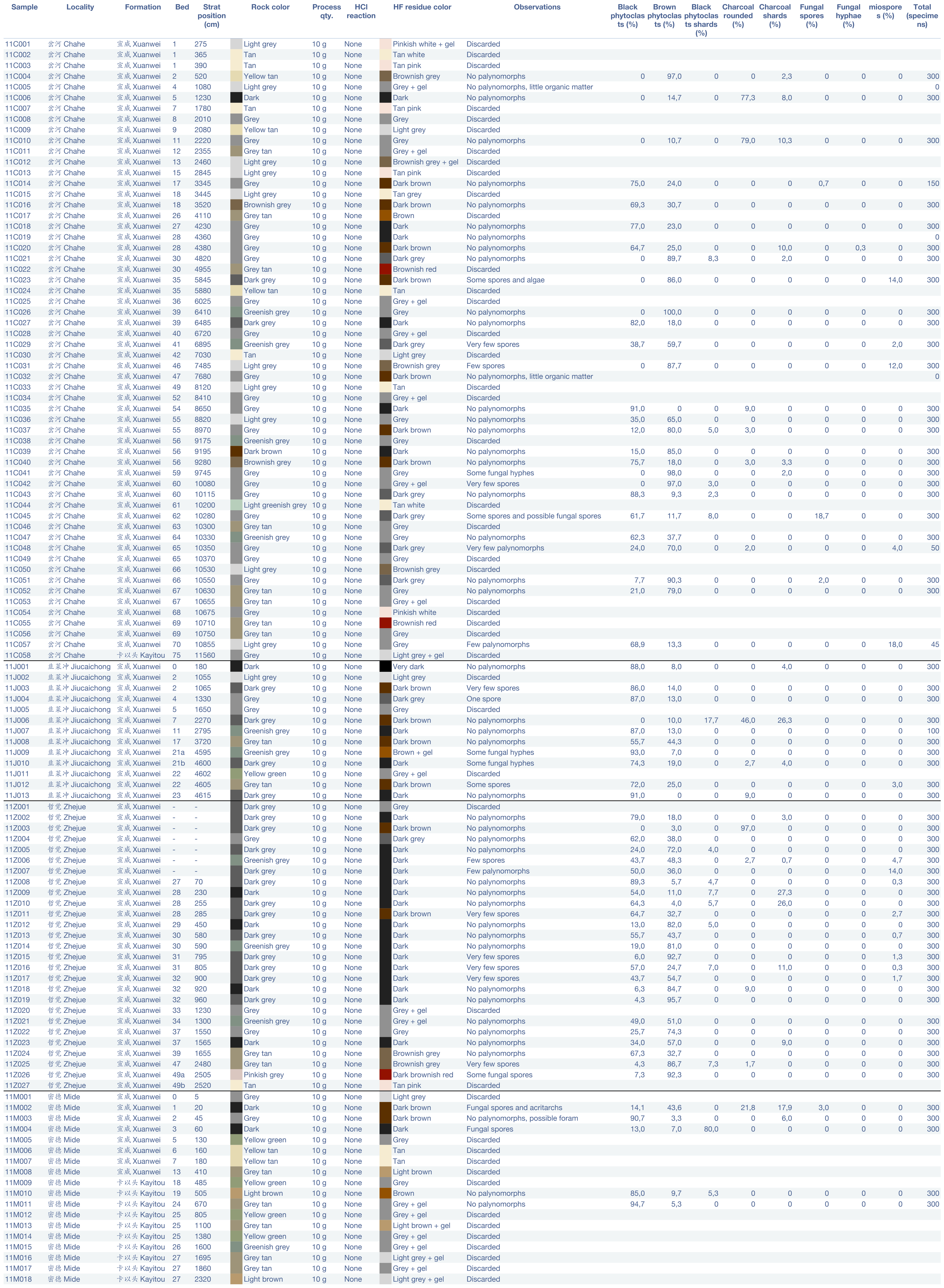


